NBER WORKING PAPER SERIES

\title{
TAXING CORPORATE INCOME
}

\author{
Alan J. Auerbach \\ Michael P. Devereux \\ Helen Simpson \\ Working Paper 14494 \\ http://www.nber.org/papers/w14494
}

\author{
NATIONAL BUREAU OF ECONOMIC RESEARCH \\ 1050 Massachusetts Avenue \\ Cambridge, MA 02138 \\ November 2008
}

This paper was prepared for The Mirrlees Review, "Reforming the Tax System for the 21st Century." The authors would like to thank Stephen Bond, Harry Huizinga, Jack Mintz, other conference participants and Al Warren and for helpful comments. The views expressed herein are those of the author(s) and do not necessarily reflect the views of the National Bureau of Economic Research.

NBER working papers are circulated for discussion and comment purposes. They have not been peerreviewed or been subject to the review by the NBER Board of Directors that accompanies official NBER publications.

(C) 2008 by Alan J. Auerbach, Michael P. Devereux, and Helen Simpson. All rights reserved. Short sections of text, not to exceed two paragraphs, may be quoted without explicit permission provided that full credit, including (C) notice, is given to the source. 
Taxing Corporate Income

Alan J. Auerbach, Michael P. Devereux, and Helen Simpson

NBER Working Paper No. 14494

November 2008

JEL No. G32,H25

\begin{abstract}
$\underline{\text { ABSTRACT }}$
Following Meade (1978), we reconsider issues in the design of taxes on corporate income. We outline developments in economies and in economic thought over the last thirty years, and investigate how these developments should affect the design of taxes on corporate income. We consider a number of tax systems which have been proposed, distinguishing them in two main dimensions: the definition of what is to be taxed, and where it is to be taxed. We suggest that a tax levied on economic rent accruing in the corporate sector, and on a destination basis, merits serious consideration. We discuss alternative approaches, including both R-based and R+F-based flow-of-funds taxes and an ACE allowance. It is the destination basis - with border adjustments for exports and imports - which primarily distinguishes our suggestions from those of Meade (1978).
\end{abstract}

\author{
Alan J. Auerbach \\ Department of Economics \\ 508-1 Evans Hall, \#3880 \\ University of California, Berkeley \\ Berkeley, CA 94720-3880 \\ and NBER \\ auerbach@econ.berkeley.edu \\ Michael P. Devereux \\ Centre for Business Taxation \\ Saïd Business School \\ Oxford University \\ Park End Street \\ Oxford OX1 1HP \\ United Kingdom \\ Michael.Devereux@sbs.ox.ac.uk
}

\author{
Helen Simpson \\ The Centre for Market and Public Organisation \\ Bristol Institute of Public Affairs \\ University of Bristol \\ 2 Priory Road \\ Bristol BS8 1TX \\ United Kingdom \\ Helen.Simpson@bristol.ac.uk
}




\section{Introduction}

The design of corporation income taxes has long raised difficult questions because of the complex structure of corporate operations, the flexibility of corporate decisions, and the need to trace the ultimate influence of taxes on corporations through to their shareholders, customers and employees and other affected groups. But the nature of these questions has evolved over the past few decades, as advances in economic theory and evidence have resolved some issues and changes in corporate practices and government policies have raised others. This paper discusses current issues in the design of a corporation tax system and specific reform proposals that have been under recent discussion.

The paper proceeds as follows. Section 2 lays out a framework for characterising different options for taxing corporate income. It describes the structure of the corporation tax system currently in operation in the UK and outlines significant reforms to the structure of the UK corporate tax system since the Meade Report. Section 3 puts these reforms in the context of changes to corporate tax systems in other countries and presents evidence on trends in corporation tax revenues and the industrial composition of revenues. Section 4 discusses developments since the Meade Report that affect the design of a corporate income tax system. These include both economic changes and advances in the research literature. We discuss the implications of increased international capital mobility and of the asymmetric treatment of debt and equity and consider how the tax system affects a firm's choice of organisational form. Section 5 considers optimal properties of corporation taxes in order to develop criteria against which options for reform can be assessed. In light of this, and the evidence presented in section 4, Section 6 considers specific options for corporation tax reform. We offer some concluding comments in Section 7.

\section{Characterising a corporate income tax system}

To aid comparison of different reforms we begin by briefly laying out a framework for characterising different options for taxing corporate income. We do so in an open economy setting, where firms' productive activity, sales, profits and shareholders can be located in 
different countries. We then place the proposals from the Meade Report and the current UK corporate tax system within this framework.

Table 1 characterises different ways of taxing corporate income in an open economy along two dimensions - the location of the tax base and the type of income subject to business tax. ${ }^{1}$ Considering the different locations, alternative tax bases are: corporate income earned in the country where productive activity takes place (source-based taxation), income earned in the residence country of the corporate headquarters or personal shareholders (residence-based taxation), or the sales (net of costs) in the destination country where the goods or services are finally consumed (destination-based taxation). Alternatives for the type of income included in the tax base are: first, the full return to corporate equity, including the normal return on investment and economic rents over and above the normal return; second, the full return to all capital investment including debt; and finally, only economic rents.

\section{Table 1. Characterising capital income tax systems}

\begin{tabular}{|c|c|c|c|}
\hline \multirow[t]{2}{*}{ Location of tax base } & \multicolumn{3}{|c|}{ Type of income subject to business tax } \\
\hline & Full return to equity & Full return to capital & Rent \\
\hline Source country & $\begin{array}{l}\text { 1. Conventional } \\
\text { corporate income tax } \\
\text { with exemption of } \\
\text { foreign source income }\end{array}$ & $\begin{array}{l}\text { 4. Dual income tax } \\
\text { 5. Comprehensive } \\
\text { Business Income Tax }\end{array}$ & $\begin{array}{l}\text { 6. Corporation tax with } \\
\text { an Allowance for } \\
\text { Corporate Equity } \\
\text { 7. Source-based cash } \\
\text { flow corporation tax }\end{array}$ \\
\hline $\begin{array}{l}\text { Residence country } \\
\text { (corporate } \\
\text { shareholders) }\end{array}$ & $\begin{array}{l}\text { 2. Residence-base } \\
\text { corporate income tax } \\
\text { with a credit for foreign } \\
\text { taxes }\end{array}$ & & \\
\hline $\begin{array}{l}\text { Residence country } \\
\text { (personal shareholders) }\end{array}$ & $\begin{array}{l}\text { 3. Residence-based } \\
\text { shareholder tax }\end{array}$ & & \\
\hline $\begin{array}{l}\text { Destination country } \\
\text { (final consumption) }\end{array}$ & & & $\begin{array}{l}\text { 8. Full destination- } \\
\text { based cash flow tax } \\
\text { 9. VAT-type } \\
\text { destination-based cash } \\
\text { flow tax }\end{array}$ \\
\hline
\end{tabular}

\footnotetext{
${ }^{1}$ This framework follows that in Devereux and Sørensen (2005)
} 
We discuss the specific systems in the table in section 6, but first it is useful to place the options discussed in the Meade Report within this framework. Meade's alternative tax bases, the real ( $\mathrm{R}$ base), real and financial ( $\mathrm{R}+\mathrm{F}$ base) and share ( $\mathrm{S}$ base) were all options for source-based taxation $^{2}$ which aimed to tax only economic rent. Taxing only economic rent can be considered desirable since it is non-distortionary, leaving the (normal) return earned by the marginal investment free of tax. Table 2 provides a simple outline of the $\mathrm{R}, \mathrm{R}+\mathrm{F}$ and $\mathrm{S}$ bases. Under these bases, taxing only rent is achieved by allowing all expenses to be deduced from taxable profits as they are incurred, essentially taxing positive (inward) and (negative) outward cash flows at the same rate. In practice, as outlined below for the UK system, many corporate tax systems do tax the normal return to capital in addition to economic rent, thus affecting the cost of capital and potentially introducing distortions in firms’ choices over different forms of finance.

Table 2. $\mathbf{R}, \mathbf{R}+\mathbf{F}$ and $S$ bases

\begin{tabular}{|c|c|c|c|}
\hline & R base & $\mathbf{R}+\mathbf{F}$ base & $\mathbf{S}=\mathbf{R}+\mathbf{F}$ base \\
\hline Inflows & $\begin{array}{l}\text { Sales of products, services, } \\
\text { fixed assets }\end{array}$ & $\begin{array}{l}\text { Sales of products, services, } \\
\text { fixed assets } \\
\text { Increase in borrowing, } \\
\text { interest received }\end{array}$ & $\begin{array}{l}\text { Repurchase of shares, } \\
\text { dividend payments }\end{array}$ \\
\hline Outflows & $\begin{array}{l}\text { Minus } \\
\text { Purchases of materials, } \\
\text { wages, fixed assets }\end{array}$ & $\begin{array}{l}\text { Minus } \\
\text { Purchases of materials, } \\
\text { wages, fixed assets }\end{array}$ & $\begin{array}{l}\text { Minus } \\
\text { Increase in own shares } \\
\text { issued, dividends received }\end{array}$ \\
\hline & & $\begin{array}{l}\text { Repayment of borrowing, } \\
\text { interest paid }\end{array}$ & \\
\hline
\end{tabular}

A further characteristic of a corporate tax system which is of relevance is its relationship with the personal tax system. This can be thought of in two dimensions. First, some businesses have a choice with respect to the system under which they are taxed, for example in the UK whether they incorporate or whether the owner of the business is registered as self-employed and taxed under the personal tax system. Differential tax treatment under these alternatives can potentially affect the choice of organisational form. The second dimension in which the interaction of the corporate and personal tax systems is of relevance is the tax treatment of shareholders in incorporated businesses. Under a classical system dividend income is taxed twice, at the

\footnotetext{
${ }^{2}$ In fact in the closed economy setting considered, source, residence and destination would all be the same location.
} 
corporate and at the personal level. Alternatively, an imputation system alleviates double taxation by making an allowance for all or some of the corporate tax already paid when calculating the income tax owed by the dividend recipient. Realised gains on equity investment may also be subject to capital gains tax at the personal level.

\subsection{The UK corporate tax system}

The UK corporate tax system taxes UK-resident companies (i.e. those with UK headquarters) on their global profits (with a credit for tax paid on profits generated abroad), and taxes non-UK resident companies on their profits generated in the UK. Corporation tax is charged on income from trading, investment and capital gains, less specific deductions. In particular the system allows interest payments to be deducted from taxable profits and can be characterised as taxing the full return to equity, rather than the full return to all capital investment. The UK system therefore comprises a combination of residence-based and source-based systems numbered 1 and 2 in table 1.

In 2007-08 the main rate of corporation tax in the UK stands at 30\% with a lower small companies’ rate of $20 \%$ for firms with taxable profits up to $£ 300,000$. Firms with taxable profits between $£ 300,001$ and $£ 1,500,000$ are subject to marginal relief so that the marginal tax rate they face on their profits above $£ 300,000$ is $32.5 \%$, and the average tax rate they face on their total profits rises gradually from $20 \%$ to $30 \%$ as total taxable profits increase. Table 3 summarises the different rates. ${ }^{3}$ In 2004-05 only around 5\% of companies paid corporation tax at the main rate, however, they accounted for $75 \%$ of total profits chargeable to corporation tax. ${ }^{4}$ See Crawford and Freedman in this volume for further discussion of the taxation of small businesses.

Current expenditure such as wages is deductible from taxable profits and firms can claim capital allowances which allow a deduction for depreciation of capital assets. For example, expenditure on plant and machinery is written down on a $25 \%$ declining balance basis, (50\% in the first year for small and medium-sized companies), and expenditure on industrial buildings is written down at $4 \%$ per year on a straight line basis, although these rates are due to change from 2008-09.

\footnotetext{
${ }^{3}$ We do not discuss the separate regime for the taxation of North Sea Oil production. See Adam, Browne and Heady in this volume for further details.

${ }^{4}$ http://www.hmrc.gov.uk/stats/corporate_tax/11-3-corporation-tax.pdf
} 
Table 3. UK corporation tax rates, 2007-08

\begin{tabular}{l|ll}
\hline Taxable profits (£ per year) & Marginal tax rate (\%) & Average tax rate (\%) \\
\hline $0-300,000$ & 20 & 20 \\
$300,001-1,500,000$ & 32.5 & $20-30$ \\
$1,500,000$ plus & 30 & 30 \\
\hline
\end{tabular}

Source: HM Revenue and Customs, http://www.hmrc.gov.uk/rates/corp.htm.

Capital expenditure related to research and development (R\&D) receives more generous treatment under the 'R\&D allowance' and receives a 100\% immediate deduction. Under the R\&D tax credit current R\&D expenditure also receives more favourable treatment than other forms of current expenditure. In 2007-08 large companies can deduct 125\% of eligible R\&D expenditure, and small and medium-sized companies can either deduct $150 \%$ of eligible expenditure, or if they are loss-making can receive the credit as a cash payment.

Since the early 1980s the UK corporation tax system has moved away from the taxation of economic rent towards taxing the full return to equity through a broadening of the tax base brought about by a reduction in the value of capital allowances. Box 1 summarises some of the main reforms. The main changes occurred during the mid-1980s with the phasing out of $100 \%$ first year allowances for plant and machinery and 50\% initial allowances for industrial buildings. ${ }^{5}$ This broadening of the tax base was accompanied by a substantial fall in the statutory rate (from $52 \%$ in $1982-83$ to $35 \%$ by 1986-87), and this type of restructuring has been mirrored in other countries as discussed in sections 3 and 4. Since the mid-1980s there have been a series of further falls in the main rate of corporation tax and in the rate of advanced corporation tax (ACT) (from 30\% in 1985-86 to 20\% in 1994-95), which was paid by the company at the time it distributed dividends. ${ }^{6}$ ACT was then abolished in 1999-00. The small companies' rate has also been reduced in line with falls in the basic rate of income tax. However from 1997-98 onwards the small companies' rate has been below the basic rate of income tax, although this situation is now due to be reversed from 2008-09. Indeed the changes announced in the 2007 budget (summarised in Box 1) move towards a broadening of the tax base and lowering of the tax rate

\footnotetext{
${ }^{5}$ The first year allowance was applied in place of the writing down allowance, while an initial allowance was applied on top of the writing down allowance.

${ }^{6}$ The remainder of the corporation tax due, mainstream corporation tax, was paid nine months after the end of a firm's financial year. After ACT was abolished a new quarterly payments system was introduced for large companies.
} 
for larger firms, and for firms paying at the small companies’ rate and benefiting from the new Annual Investment Allowance, a narrowing of the tax base and an increase in the tax rate.

\section{Box 1. UK corporate tax reforms since the Meade Report}

In 1978 at the publication of the Meade Report, the main CT rate was 52\% and the small companies' rate $40 \%$. There was a first year allowance of $100 \%$ for plant and machinery and an initial allowance of $50 \%$ for industrial buildings. Yearly writing down allowances were $25 \%$ for plant and machinery (reducing balance) and $4 \%$ for industrial buildings (straight line).

1983: Small companies' rate cut from $40 \%$ to $38 \%$ from $1982-83$.

1984: Announcement of stepwise reduction in CT rates, from $52 \%$ in $1982-83$ to $35 \%$ in 1986/87. First year and initial allowances phased out by 1986/87. Small companies' rate cut in one step to $30 \%$ from 1983-84.

1986: Small companies' rate cut from $30 \%$ to $29 \%$.

1987: Small companies' rate cut from $29 \%$ to $27 \%$.

1988: Small companies' rate cut from $27 \%$ to $25 \%$.

1991: CT rate cut from $35 \%$ to $34 \%$ in $1990-91$ and to $33 \%$ from $1991-92$.

1992: Temporary enhanced capital allowances between November 1992 and October 1993. First-year allowance of $40 \%$ on plant and machinery and initial allowance of $20 \%$ on industrial buildings.

1995: Small companies' rate cut from $25 \%$ to $24 \%$.

1996: Small companies’ rate cut from $24 \%$ to $23 \%$.

1997: Main CT rate cut from 33\% to 31\%. Small companies' rate cut from $23 \%$ to $21 \%$. Windfall tax imposed on privatised utilities. Repayment of dividend tax credits abolished for pension funds.

1998: Main CT rate cut from 31\% to 30\%, small companies' rate cut from $21 \%$ to $20 \%$ from $1999-00$. ACT abolished from 1999-00. System of quarterly instalment tax payments phased in from 1999-00. Repayment of dividend tax credits abolished for tax-exempt shareholders and rate of dividend tax credit reduced from $20 \%$ to $10 \%$ from $1999-00$.

1999: New starting rate for small companies introduced at $10 \%$ from $2000-01$.

2002: Small companies' rate cut from $20 \%$ to $19 \%$. Starting rate cut from $10 \%$ to $0 \%$.

2004: Minimum rate of $19 \%$ for distributed profits introduced.

2006: $0 \%$ starting rate abolished 2006-07.

2007: Small companies' rate increased to $20 \%$ in 2007-08. Further increases announced, to $21 \%$ in 200809 and $22 \%$ in 2009-10. Main CT rate to be cut from 30\% to 28\% in 2008-09. New Annual Investment Allowance introduced from 2008-09 allowing 100\% of the first £50,000 of investment in plant and machinery to be offset against taxable profits. From 2008-09 general plant and machinery writing down allowance to be reduced from $25 \%$ to $20 \%$ and writing down allowances on industrial buildings to be phased out. 


\section{Trends in corporation tax rates and revenues}

The base-broadening, rate-cutting reforms to the structure of the UK corporation tax in the mid1980s have also been carried out in other countries. Figures 1 and 2 show that both statutory corporation tax rates and the value of depreciation allowances have been falling across the G7 economies. Figure 1 shows falling statutory rates, and for this group of countries some evidence of convergence to main rates between $30 \%$ to $40 \%$. There are some differences in the timing of cuts in statutory rates across countries. The figure shows the UK and USA making significant cuts to the main rate in the mid 1980s, whereas Italy (having previously raised the main rate), Japan and Germany only make significant cuts from the late 1990s onwards. Figure 2 shows declines in the present discounted value of depreciation allowances; most noticeably the significant base-broadening reform in the UK in the mid-1980s. The implications of these reforms for the effective tax rates faced by companies are discussed further in section 4 .

Figure 1. Statutory corporation tax rates

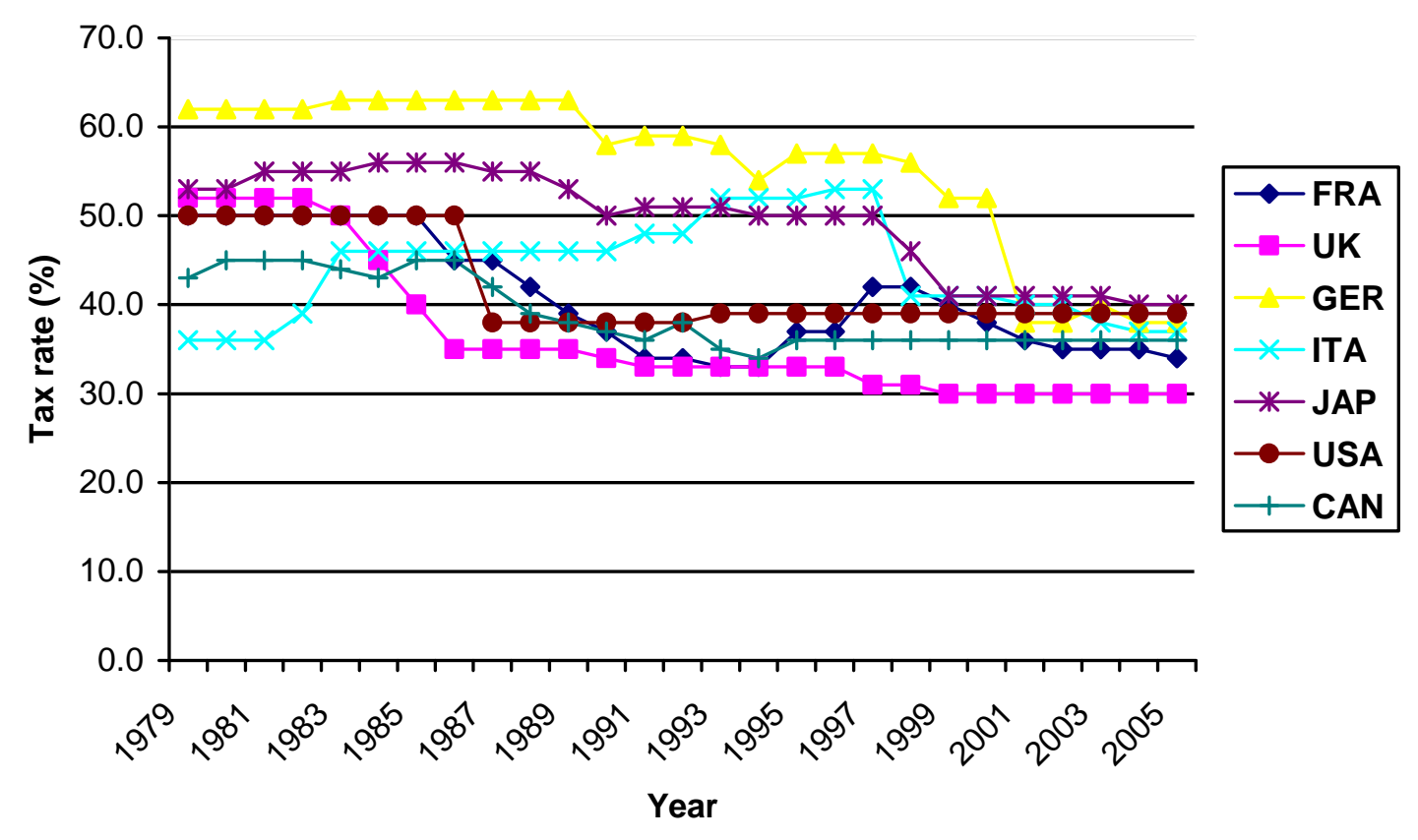

Source: Devereux, Griffith and Klemm (2002), updated, table A1. For countries applying different rates the manufacturing rate is used. http://www.ifs.org.uk/publications.php?publication_id=3210 
Figure 2. Present Discounted Value of depreciation allowances

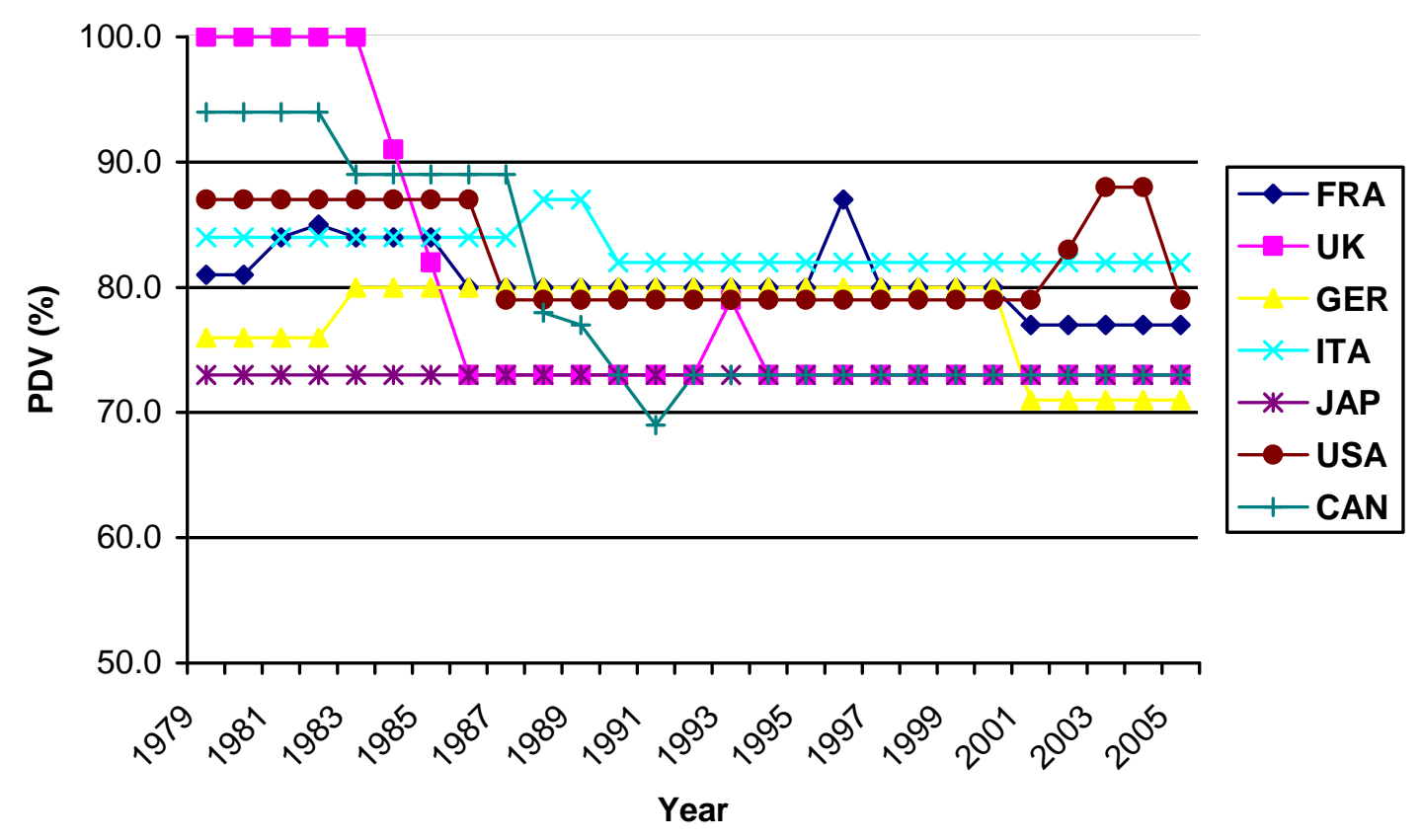

Notes: Definition: The PDV of allowances is calculated for an investment in plant and machinery. Special first year allowances are included if applicable. Where switching between straight-line and reducing balance methods is allowed, such switching is assumed at the optimal point. The assumed real discount rate is $10 \%$, the assumed rate of inflation is 3.5\%. For countries applying different rates the manufacturing rate is used.

Source: Devereux, Griffith and Klemm (2002), updated, table A2 http://www.ifs.org.uk/publications.php?publication_id=3210

For the UK these reforms have not led to significant changes in the share of corporation tax receipts in total tax revenues, or in corporation tax receipts measured as a share of GDP. Figure 3 shows corporation tax revenues as a share of total tax receipts for the G7 over the period 1970 to 2004. Although there is some fluctuation over the period corporation tax revenues in the UK make up around $8 \%$ of total UK tax revenues at the beginning and end of the period. For the remaining G7 countries, other than for Japan there is no evidence of a substantial decline in the share of corporation tax revenues in total tax receipts. Figure 4 shows that UK corporation tax revenues comprised between $2 \%$ and $4 \%$ of GDP over the period. Though falls in corporation tax revenues as a proportion of GDP generally coincide with periods of recession, the decline in 2002 and 2003 appears to be an anomaly. 
Figure 3. Corporation tax revenues as \% total tax revenues

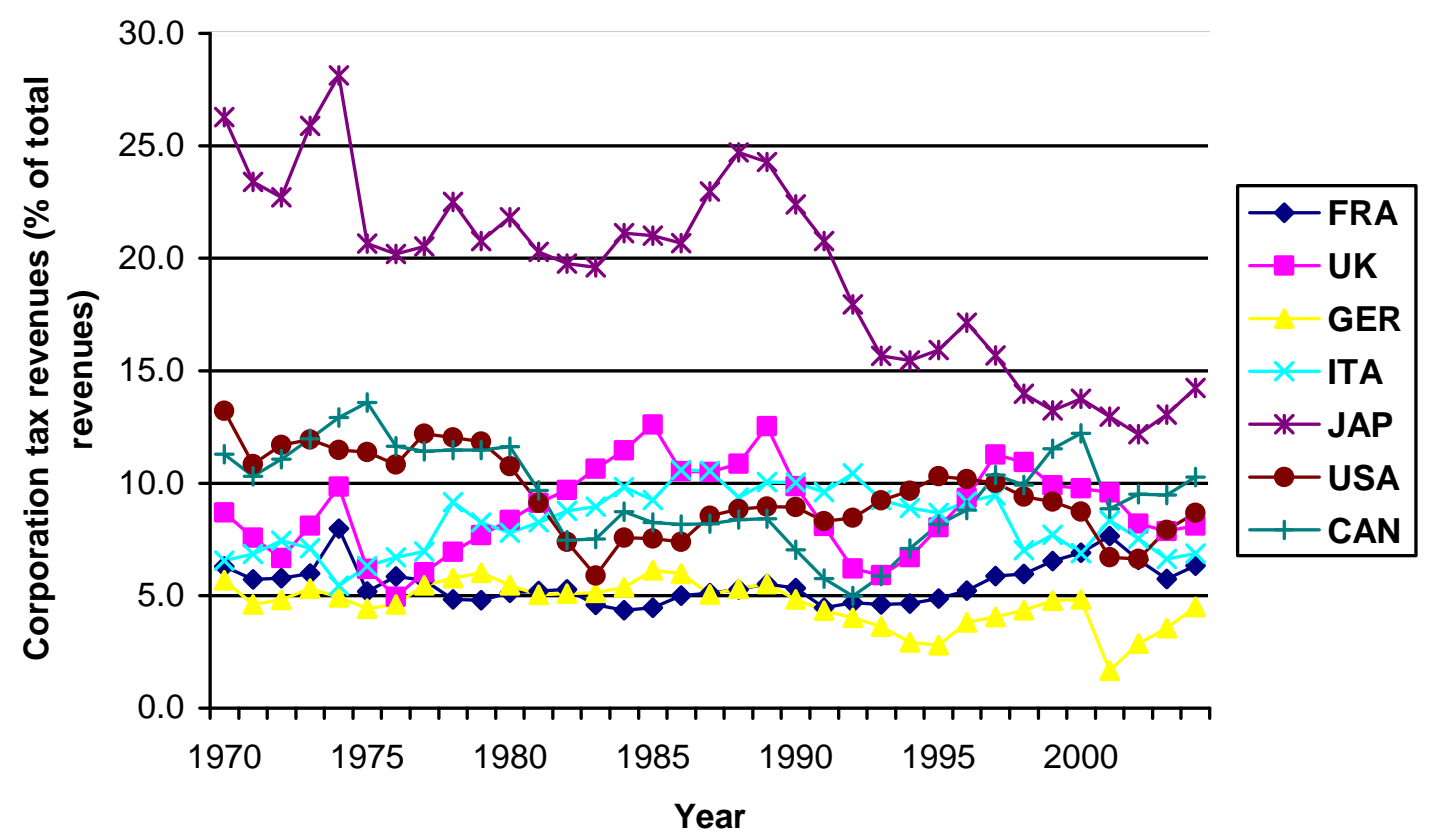

Source: OECD Revenue Statistics

Figure 4. UK corporation tax revenues as a \% of GDP

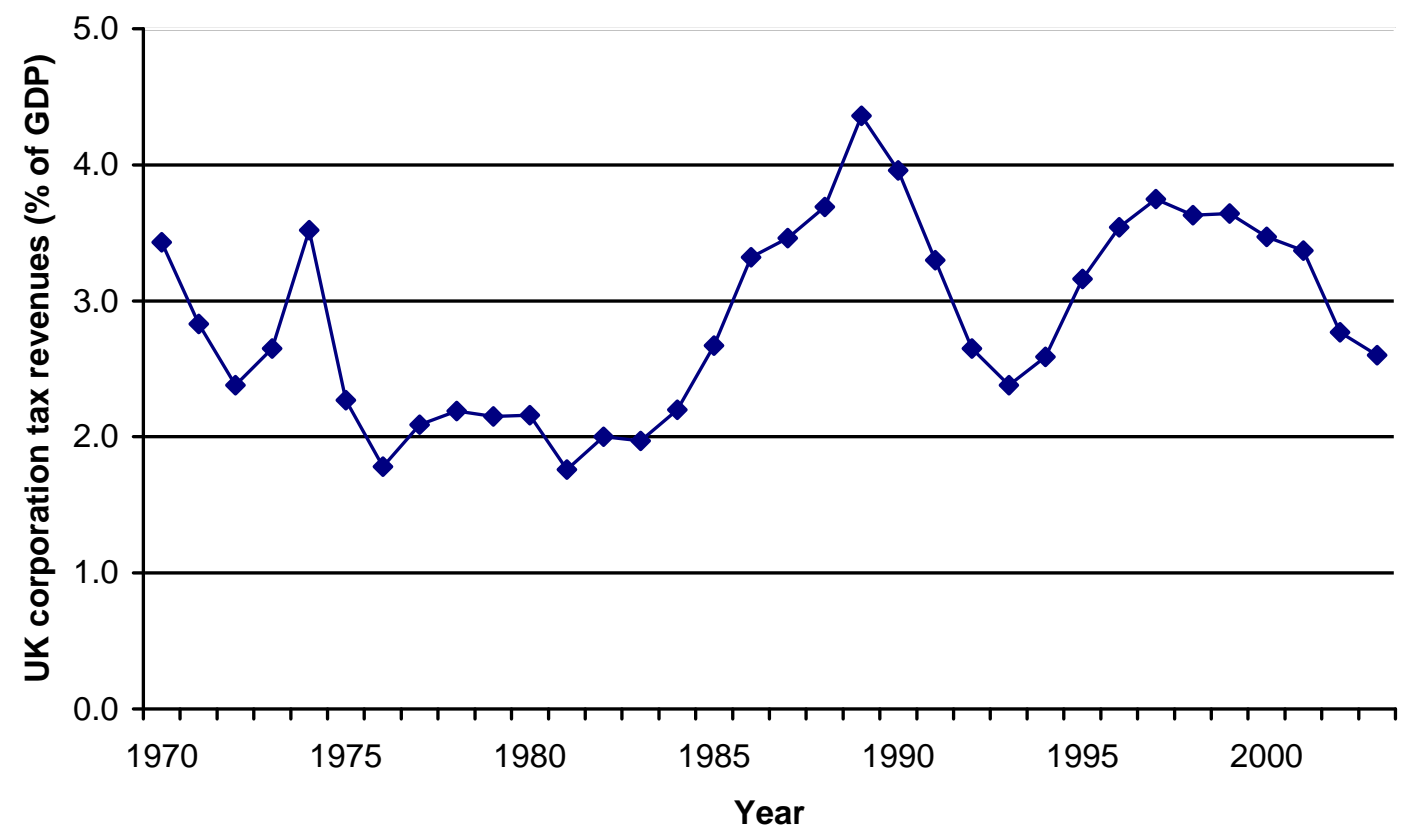

Source: Financial Statistics, Office for National Statistics 
Devereux, Griffith and Klemm (2004) also consider evidence on the size of the corporate sector and on rates of profitability underlying UK corporate tax revenues. Using data for the nonfinancial sector they do not find any evidence of a significant change in the rate of profitability for this sector of the economy from 1980 to 2001. They find some evidence of an expansion in the size of the corporate sector (measured by profits as a share of GDP), which, given the evidence on the profitability rates in the non-financial sector, they conclude could be due to some combination of a general expansion or an increase in profitability in the financial sector.

For the UK and the US there is evidence of significant changes in the sectoral composition of revenues, most strikingly in the share of total corporate tax revenues accruing from the financial sector. Since the early 1980s, in the UK there has been a substantial increase in the share of total profits that are chargeable to corporation tax arising in the banking, finance and insurance sector, (and in service sectors more broadly) and a decrease in the manufacturing sector share. Figure 5 shows that the increase in the share due to financial corporations is also mirrored in the US. The two countries show an increase from around $5 \%$ to $10 \%$ in the early 1980 s to over $25 \%$ of corporation tax revenues in 2003. This increased importance of the financial sector demonstrates that discussion of reforms to the corporation tax system should consider implications for both the financial and non-financial sectors.

Finally, Auerbach (2006) presents evidence for the US on a further factor underlying the continued strength of corporation tax revenues - an increase in recent years in the value of losses relative to positive taxable income. Since taxable income and losses are treated asymmetrically under corporation tax systems, (losses do not receive an immediate rebate and firms may have to wait until they earn sufficient taxable profits to offset them, and may also face a delay in claiming capital allowances thus reducing their value), this increase in the value of losses led to an increase in the average tax rate on net corporate profits (positive income net of losses). This trend may signal a need to re-examine this asymmetry within corporate tax systems and the extent to which it distorts investment decisions. 
Figure 5. Taxes on financial corporations as a share of corporate tax revenues, UK and US

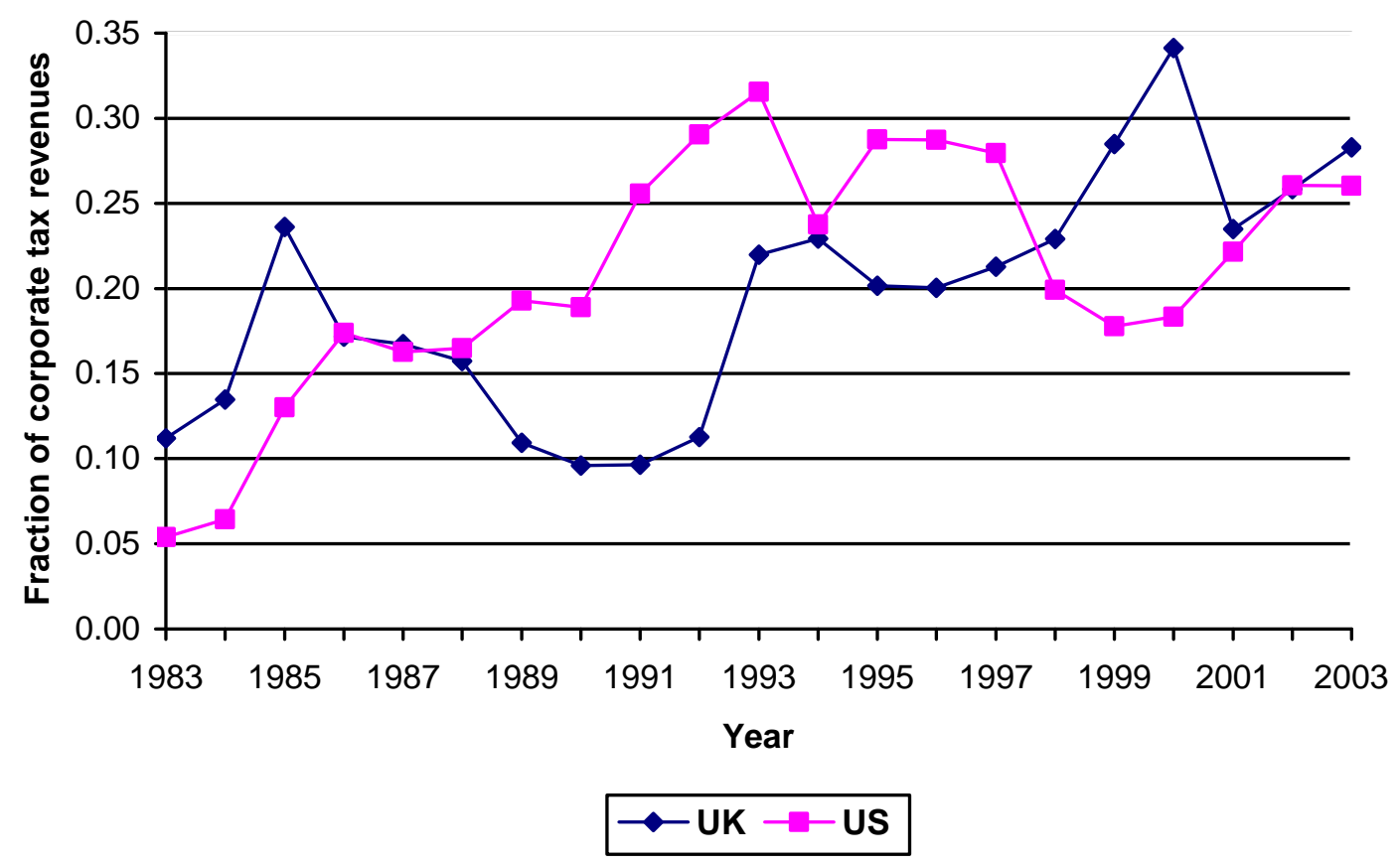

Sources: Internal Revenue Statistics, Statistics of Income; HM Revenue and Customs; Office for National Statistics.

In summary the evidence suggests that corporate tax revenues have continued to make a substantial contribution to total tax receipts despite falls in statutory rates. A potential driver of these reductions in corporation tax rates is increased tax competition between countries seeking to attract mobile capital. We consider this issue in more detail in section 4, together with evidence on other economic developments and advances in the academic literature affecting the design of corporation tax systems.

\section{Developments affecting the design of a corporate income tax system}

In this section we trace important developments since the Meade Committee reported, and identify how they might affect the design of tax policy. These developments are of several forms.

There have clearly been changes in the economic position of the UK and of the rest of the world. The most prominent is globalisation; and in particular, the rise of international flows of capital and of profit. This raises several issues which were not fully discussed by the Meade Committee. For example, in a globalised world, the owner (typically the supplier of equity finance) of an 
investment project may be resident in a different jurisdiction from where the project is undertaken; which may be different again from where the consumer of the final product may reside. This raises several important and difficult questions.

First, where is profit generated? And is this actually an appropriate question for taxation should the international tax system attempt to tax profit where it is located, or on some other basis? To the extent that the international tax system aims to identify the location of profit and tax it where it is located, then there are incentives for multinational companies to manipulate the apparent location of profit (conditional on where real economic activity takes place) in order to place it in a relatively lightly taxed country.

Second, another aspect of this difference in jurisdiction between activity and owner is the role of personal taxes. At the time the Meade committee reported, many countries - especially in Europe - had some form of integration of corporate and individual taxes. For example, the UK had an imputation system, under which UK shareholders received a tax credit associated with a dividend payment out of UK taxable income; this credit reduced the overall level of tax on UK sourced corporate profit distributed to UK shareholders. But increasingly the ownership of UK companies has passed to non-UK residents. The relevance of such a tax credit for efficiency or equity purposes is therefore open to question.

A third consequence of globalisation is that companies make discrete investment choices: for example, whether to locate an operation in the UK or Ireland. Although there may be many other examples of discrete choices (whether to undertake R\&D or not, whether to expand into a new market or not), it is the discrete location choice which has received most attention to date. The influence of tax on a discrete investment choice is rather different from the case analysed by Meade, and the flow-of-funds taxes advocated by Meade would not generally be neutral with respect to discrete choice.

A fourth aspect of increased globalisation is tax competition between countries. In order to attract internationally mobile capital into their jurisdiction, governments have to offer a business environment at least comparable to that available elsewhere. The taxation of profits is part of that environment. Consequently, there has been downward pressure on various forms of tax rates, as globalisation and other factors have led to lower statutory and effective tax rates. 
There have also been developments in the type of economic activity seen in the UK and other major industrialised countries. Manufacturing has played a decreasing role in the economy; services and the financial sector are now very much more important. This suggests that at least one of the traditional aspects of corporation taxes - the rate of depreciation allowed on buildings and plant and machinery - has shrunk in importance. By contrast, investment in intangibles and financial assets has become more important. Incentives for $R \& D$ are common. Also, the taxation of profit in the financial sector is quantitatively more important.

Part of the development of the financial sector has involved innovation in financial products. The traditional distinction between debt and equity is much less clear than it might have appeared to the Meade Committee. The combination of characteristics which apply to traditional debt are that it has a prior claim to income generated, it receives a return which is determined in advance (in the absence of bankruptcy), and that debt-holders typically do not have voting rights. But there is no reason for a single financial instrument to have either all or none of these characteristics. If an instrument has only one or two of these characteristics, it may be difficult to define as debt or equity. This issue becomes still more complex when combined with the effects of globalisation, where countries may not take the same view as to whether an instrument qualifies as debt and therefore whether the return should be deductible in the hands of the borrower and taxable in the hands of the lender.

There have also been developments in economic theory. One important development returns to the role of personal taxes. The "new view" of dividend taxation states that under some circumstances dividend taxes do not affect investment decisions. If at the margin investment is financed by retained earnings and the tax rate on dividend income remains constant, then the net cost to the shareholder is reduced by dividend taxes at exactly the same rate at which the eventual return is taxed. These two effects cancel out to leave the required rate of return unaffected, and hence the effective marginal tax rate equal to zero. In fact this is a very similar effect to that generated by the S-based corporation tax analysed by the Meade Committee, since taxes on net distributions are a form of cash flow tax. The same argument would apply to investment financed by new share issues if a tax credit were associated with the new issue, as would be the case under the S-base. 
In the remainder of this section we look in more detail at some of these developments. We begin by considering aspects of globalisation: how does international integration affect the manner in which taxes can affect business decisions? We then briefly consider the issue of tax competition among countries. Next we turn to consider how developments in financial markets, and particularly in financial instruments, affect the choice of whether a tax regime should differentiate between debt and equity. Finally, we address issues in personal taxation, and consider whether integration of corporate and personal taxes is a necessary feature of overall taxes on profit.

In each of these cases, we examine in principle how taxes can create distortions. We also briefly summarise evidence on the extent to which business decisions are affected by tax, and investigate the implications for tax design.

\subsection{Decisions of multinational corporations}

A useful approach to considering the impact of corporation taxes on flows of capital and profit is to first describe a simple approach to understanding the choices of multinational firms. The model described here is a simple extension of the basic model of horizontal expansion of multinational firms, drawing specifically on Horstman and Markusen (1992). Many extensions are examined by Markusen (2002), but it is not necessary to address them in any detail here.

To understand the effects of tax, it is useful to consider a simple example. Suppose a US company wants to enter the European market. It is useful to think of four steps of decisionmaking. First, a company must make the discrete choice as to whether to enter the market by producing at home and exporting, or by producing abroad. To make this discrete choice, the company must assess the net post-tax income of each strategy. Exporting from the USA to Europe will incur transport costs per unit of output transported. Producing in Europe will eliminate, or at least reduce, transport costs, but may incur additional fixed costs of setting up a facility there. The choice therefore depends on the scale of activity, and the size of the various costs. The scale of the activity would depend on the choices made in stages 2 to 4 below.

What is the role of corporation taxes in this decision? If production takes place in the USA, then the net income generated would typically be taxed in the USA. If production takes place in a European country, then the net income generated will generally be taxed by the government in 
that country. There may be a further tax charge on the repatriation of any income to the USA. Taking all these taxes into account, the company would choose the higher post-tax profit. Conditional on a pre-tax income stream, the role of tax is captured by an average tax rate essentially the proportion of the pre-tax income which is taken in tax.

If the company chooses to produce abroad, the second step faced by the company is where to locate production. The company must choose a specific location within Europe to produce, for example within the UK or Germany. This is a second discrete choice. The role of tax is similar to that in the first discrete choice, and can be measured by an average tax rate.

The third step represents the traditional investment model in the economics literature, and the one considered by the Meade Committee: conditional on a particular location - say the UK - the firm must choose the scale of its investment. This is a marginal decision. The company should invest up to the point at which the marginal product of capital equals the cost of capital. As such the impact of taxation should be measured by the influence of the tax on the cost of capital determined by a marginal tax rate. Under a flow-of-funds tax, such as proposed by the Meade Committee, this marginal tax rate is zero; the tax therefore does not affect this third step in decision-making.

In a slightly different model, this third step might play a more important role. Suppose that the multinational firm already has production plants in several locations. If it has unused capacity in existing plants, then it could choose where to generate new output amongst existing plants. The role of tax would again be at the margin, in that the company need not be choosing between alternative discrete options. However, note that this is a different framework: in effect, it implies that the firm has not already optimised investment in each plant up to the point at which the marginal product equalled the cost of capital.

The fourth step in the approach described here is the choice of the location of profit. Having generated taxable income, a company may have the opportunity to choose where it would like to locate the taxable income. Multinationals typically have at least some discretion over where taxable income is declared: profit can be located in a low tax rate jurisdiction in a number of ways. For example, lending by a subsidiary in a low tax jurisdiction to subsidiary in a high tax jurisdiction generates in a tax-deductible interest payment in the high tax jurisdiction and additional taxable income in the low tax jurisdiction. Hence taxable income is shifted between 
the two jurisdictions. The transfer price of intermediate goods sold by one subsidiary to the other may also be very difficult to determine, especially if the good is very specific to the firm. Manipulating this price also gives the multinational company an opportunity to ensure that profit is declared in the low tax jurisdiction rather than the high tax jurisdiction.

Of course, there are limits to the extent to which multinational companies can engage in such shifting of profit. (If there were no limit, then we should expect to observe all profit arising in a zero-rate tax haven, with no corporation tax collected elsewhere). Indeed, companies can argue that complications over transfer prices may even work to their disadvantage: if the two tax authorities involved do not agree on a particular price, then it is possible that the same income may be subject to taxation in both jurisdictions. ${ }^{7}$

Broadly, one should expect the location of profit to be determined primarily by the statutory tax rate. It is plausible to suppose that companies take advantage of all tax allowances in any jurisdiction in which they operate. Having done so, their advantage in being able to transfer a pound of profit from a high-tax jurisdiction to a low-tax one depends on differences in the statutory rate. ${ }^{8}$ However, many of the complications of corporation tax regimes have been developed precisely to prevent excessive movement of profit; so there are many technical rules which are also important.

There is growing empirical evidence of the influence of taxation on each of the four steps outlined here. For example, Devereux and Griffith (1998) presented evidence that the discrete location decisions of US multinationals within Europe were affected by an effective average tax rate rather than an effective marginal tax rate. Similar evidence has been found by subsequent papers. ${ }^{9}$ The estimated size of the effects of taxation on the allocation of capital across countries is typically much larger than the estimated size of the effect of taxation on the scale of investment in a given country.

\footnotetext{
${ }^{7}$ On the other hand, operating in jurisdictions with different rules regarding the measurement of revenues and deductions also provides multinational companies with scope to structure financial arrangements so that some revenues may not generate tax liability anywhere and some expenses may be deductible in more than one country.

${ }^{8}$ It may also depend on withholding taxes and the tax treatment the parent company.

${ }^{9}$ Earlier papers used measures of average tax rates, but did not do so explicitly with the intention of testing the effect of tax on discrete choices; typically they were used as a proxy for effective marginal tax rates.
} 
There is also a large empirical literature that investigates the impact of tax on the location of taxable income. This literature has three broad approaches: a comparison of rates of profit amongst jurisdictions; an examination of the impact of taxes on financial policy, especially the choice of debt and the choice of repatriation of profit; and other indirect approaches have also been taken, including examining the choice of legal form, the pattern of intra-firm trade and the impact of taxes on transfer prices. Much of the literature has found significant and large effects of tax on these business decisions.

The four-stage problem outlined above involves three different measures of an effective tax rate. The first two discrete choices depend on an effective average tax rate. The third stage depends on an effective marginal tax rate. And the fourth depends on the statutory tax rate. This makes the tax design problem complicated. It is possible to design a tax system which generates a zero effective marginal tax rate, and this is what the Meade Committee proposed. But this clearly does not ensure neutrality with respect to all of the four decisions outlined here. Eliminating tax from having any influence on these decisions could only be achieved if the effective marginal tax rate were zero and the effective average tax rate and the statutory tax rate were the same in all jurisdictions. This would clearly require a degree of international cooperation which is beyond reasonable expectation. However, while achieving complete neutrality with respect to the location of capital and profit would be beneficial from a global viewpoint, as noted above, this may not be true from the view point of any individual country.

\subsection{Tax competition}

Tax competition can clearly result from a situation in which governments do not cooperate with each other. In that case, governments may seek to compete with each other over scarce resources.

The factor most commonly considered as a scarce resource in the academic literature is capital the funds available for investment. In a small open economy, the post-tax rate of return available to investors is fixed on the world market. Any local tax cannot change the post-tax rate of return to investors, but must raise the required pre-tax rate of return in that country; this would generally be achieved by having lower capital located there. Strategic competition would be introduced in a situation where there were a relatively small number of countries involved in 
attempting to attract inward investment. In this case the outcome of such competition would depend on the degree to which capital is mobile across countries and the cost to the government of raising revenue from other sources. In line with the discussion above, such competition may be over average tax rates for discrete choices, over marginal tax rates for investment, and over statutory tax rates for the shifting of profits. Overall, governments may be competing over several different aspects of corporation taxes. ${ }^{10}$

Several empirical papers, largely in the political science literature, attempt to explain corporation tax rates with a variety of variables, including political variables, the size of the economy, how open it is, and the income tax rate. Some of these papers start from the premise of competition. However, we know of only two papers which attempt to test whether there is strategic international competition in corporation taxes. ${ }^{11}$ These papers find empirical support for the hypothesis that tax rates in one country tend to depend on tax rates in other countries; there is support for the hypothesis that other countries follow the USA, but also for more general forms of competition.

What role does competition play in the design of corporation taxes? Essentially it acts as a constraint. In a closed economy, in principle, a flow-of-funds tax could be levied at a statutory rate of $99 \%$ and still have no distorting effect on investment; the effective marginal tax rate which affects investment in such a setting remains zero even with a very high tax rate. ${ }^{12}$ However, in open economies, competition would almost certainly rule out a very high statutory rate, and might also constrain the choice of effective marginal and average tax rates. This might affect the design of the tax system. If there were a specific revenue requirement, and an upper limit on the tax rate, for example, the revenue might be achieved only by broadening the tax base - which in turn implies increasing the marginal tax rate and hence distorting investment decisions. This creates a trade-off in competition for capital and competition for profit, although governments can in principle use the two tax instruments of the rate and base to compete for both simultaneously.

\footnotetext{
${ }^{10}$ Haufler and Schjelderup (2000) and Devereux et al (2006) analyse the case of simultaneous competition over the statutory rate and a marginal rate; there have been no studies attempting to model competition also over an average rate.

${ }^{11}$ Altshuler and Goodspeed (2000) and Devereux et al (2006).
} 


\subsection{Debt versus equity}

The Meade report recognized the differing tax treatment of income accruing to owners of debt and equity as a source of economic distortion, and recommended alternative methods of taxing business returns - utilizing the $R, R+F$ and $S$ bases as discussed earlier in the chapter - aimed at removing the influence of taxation from the debt-equity choice. Under each of these tax bases, the returns to marginal investment financed by debt and equity each would be taxed at an effective rate of zero, so in principle neither the investment decision nor the financial decision would be distorted.

In the years since the Meade report, several developments have shaped consideration of how to reform the tax treatment of corporate debt and equity. First, empirical research has clarified the strength of the behavioural response of corporate financial decisions to taxation. Second, financial innovation has raised questions about the ability of tax authorities to distinguish debt from equity, highlighting the potential problems of tax systems seeking to distinguish between debt and equity. Indeed, as will be discussed, such problems might arise even under the Meade report's reformed tax bases in spite of their apparently neutral treatment of debt and equity.

\subsubsection{Taxation and the debt-equity decision}

With a classical tax system that permits the deduction of interest payments but, until 2003, offered no offsetting tax benefits for the payment of dividends, the United States has taxed equity and debt quite differently and therefore offers an opportunity to consider the behavioural response of corporate financial decisions. But uncovering corporate financial responses to this disparate treatment is not straightforward, given that the U.S. corporate tax rate has changed relatively infrequently over time and that essentially all corporations face the same marginal tax rate on corporate income. The major identifying strategy utilized in empirical research in the years since the Meade report has been based on the asymmetric tax treatment of income and losses, under which income is taxed as it is earned but losses can generate a commensurate refund only to the extent that they can be deducted against the corporation's prior or future

\footnotetext{
12 This abstracts, of course, from other domestic activities that might be influenced by a high statutory tax rate, such as managerial effort or the diversion of corporate resources.
} 
years' income. For firms with current losses and without adequate prior income to offset these losses, the need to carry losses forward without interest (and subject eventually to expiration) reduces the tax benefit of additional interest deductions.

Calculations by Altshuler and Auerbach (1990) for the early 1980s suggested that tax asymmetries were quantitatively important for the U.S. corporate sector as a whole and that there was also considerable heterogeneity with respect to the value of interest deductions, depending on a corporation's current and recent tax status. Thus, tax asymmetries did provide a useful source of variation in the tax incentive to borrow. Using a somewhat different methodology, Graham (1996) also found considerable variation across firms in the potential tax benefit of additional interest deductions, and used this variation to assess the influence on corporate decisions, finding a significant response. This confirmed the results of earlier empirical research that used cruder measures of tax status as determinants of borrowing. ${ }^{13}$ Related research has found an influence of a company's tax status on its decision to lease equipment rather than borrowing to purchase it, the lease providing a method of shifting the interest and investmentrelated deductions to a lessor with potentially greater ability to utilize deductions immediately.

The observed reaction of borrowing to tax incentives confirms that the tax treatment of debt and equity influences corporate financial decisions, although it does not show that economic distortion is minimized when debt and equity are treated equally. Another strand of the literature on corporate behaviour, dating from Berle and Means (1932) and revived especially in the years following the Meade report, emphasizes the distinction between corporate ownership and control and the potential divergence of interests between corporate managers and shareholders. This work suggests that the decisions of executives may not be efficient or in the shareholders' interest. In this setting, tax distortions need not reduce economic efficiency, and this is relevant for the tax treatment of borrowing, given that some, notably Jensen (1986), have argued that the increased commitments to pay interest serve as an incentive to elicit greater efforts from entrenched managers. Thus, while a tax bias in favour of interest appears to encourage borrowing, it is harder to say whether it encourages too much borrowing.

\footnotetext{
${ }^{13}$ See Auerbach (2002) for a survey of this and related research discussed below.
} 


\subsubsection{Financial innovation}

The literature provides unfortunately little guidance as to how taxes on financial decisions might be used to offset managerial incentive problems. But recent developments in financial markets cast this issue in a different light. By blurring the debt-equity distinction and potentially transforming the debt-equity decision into one of minor economic significance (tax treatment aside), financial innovation may have lessened any potential benefits of encouraging corporate borrowing and moved us more toward a situation in which corporations incur real costs in order to achieve more favourable tax treatment but are otherwise unaffected in their behaviour.

The empirical results mentioned above, showing the sensitivity of leasing to tax incentives, provide on example of how borrowing may be disguised or recharacterised to take advantage of tax provisions. But many more alternatives have gained popularity over the years. The basic thrust has been to narrow the distinction between debt and equity through the use of financial derivatives and hybrid instruments.

Starting with the Black-Scholes (1973) option-pricing model, it has been come to be understood how the prices of shares and derivatives based on these shares must be related in a financial market equilibrium in which investors can hold the same underlying claims in different form. Relevant to the debt-equity decision, one can move from a position in shares to a position in debt by selling call options and purchasing put options, with the "put-call parity theorem" indicating that the two positions, being essentially perfect substitutes, should have the same market value. But when the tax treatment of these equivalent positions differs at the individual and corporate levels, the incentive is to choose the tax-favoured position, a choice that is essentially unrelated to the other activities of the corporation.

Legal restrictions have been attempted but are difficult to implement, given the many alternative methods of using derivatives to construct equivalent positions, methods that have grown in popularity as financial transaction costs have declined. ${ }^{14}$ The result has been a growth in the issuance of so-called "hybrid" securities, based on ordinary debt and structured with enough similarity to debt to qualify for favourable tax treatment but also incorporating derivatives designed to allow the securities to substitute for regular equity. Figure 6 shows the volumes in

\footnotetext{
${ }^{14}$ For further discussion, see Warren (2004).
} 
the main categories of U.S. hybrid-security issues for the period 2001-5, along with the volume of common equity issues, confirming that hybrid securities have become a significant source of funds for corporations.

Figure 6. Issues of U.S. Hybrid Securities

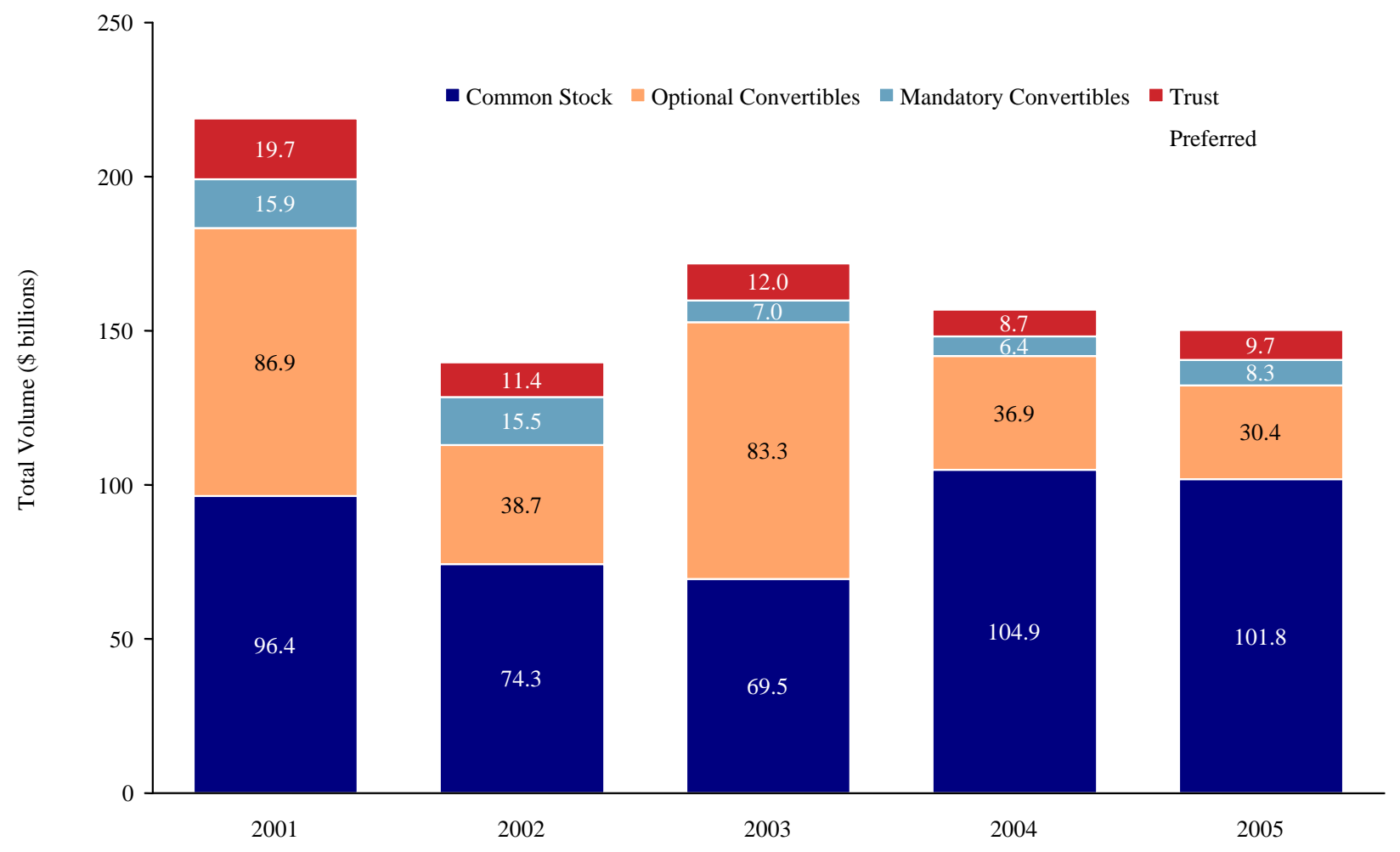

Source: Goldman, Sachs; issues of common stock include primary and combined (primary + secondary) issues but exclude purely secondary issues

\subsubsection{Implications for tax reform}

In light of financial innovation and the blurring of the distinction between debt and equity, how should one view the Meade report's recommendations for taxing business activities? Under the $R$ base, no distinction is made between debt and equity. Regardless of how funds are raised, there are no taxes on the flows between businesses and their investors. Thus, businesses may choose among debt, equity and hybrid securities without consideration of the tax consequences. Under the $R+F$ base, however, a timing distinction would remain between debt and equity, with equity being ignored by the tax system and debt being provided an effective marginal tax rate of zero 
through offsetting taxes on borrowing and interest and principal repayments. Assuming that tax rates are constant over time, the timing distinction is minor for marketable securities issued at arm's length. But related-party transactions could take advantage of the difference by reporting lower payments to equity and higher payments to debt, thereby converting tax-free payments into tax-deductible payments to the same investors. The $R$ base would seem a preferable policy to the $R+F$ base from this perspective, but an offsetting factor is the treatment of real and financial flows in product markets, in the interactions not with investors but with customers.

Under the $R+F$ base, real and financial transactions with customers are treated symmetrically, with sales subject to taxation and expenses deductible. Under the $R$ base, financial proceeds and expenses are ignored, so that firms providing the same customers with both real and financial products have an incentive to overstate the profits from financial services and understate the

profits from real activities. A related problem concerns financial companies, a sector that, as discussed earlier, has been growing steadily in importance in the UK. The returns that financial companies earn from the spreads generated by financial intermediation are automatically picked up by the $R+F$ base but ignored under the $R$ base.

Innovation in finance thus favours the $R$-base version of the Meade report's company tax system, while the growing importance of companies that specialize or engage in providing financial services calls for the $R+F$ base. Which approach is to be preferred is discussed further below, but the benefits of either approach are clear in comparison to a system that attempts to maintain an even greater distinction between debt and equity.

\subsection{Relationship between corporate and personal income taxes}

Traditionally, the corporation income tax has been seen as imposing an extra level of taxation on investment in the corporate sector, thereby discouraging corporate investment activity and shifting capital from the corporate sector to the non-corporate sector. The alternatives offered by the Meade report were aimed to remove this distortion of investment activity. However, the report devoted relatively little attention to the level at which taxes were imposed - investor or company - or to the choices other than the level of investment or the method of finance (already discussed) that might be distorted by the corporate tax, notably the choice of a company's organizational form. In the years since, the theoretical and empirical research has considered 
how corporate-level and investor-level taxes may vary in their effects on investment, and how corporate taxation influences the choice of organizational form and other corporate decisions. As a result, we have a different perspective on both the priorities and the potential alternatives for corporate tax reform.

\subsubsection{Corporate and personal income taxes and the incentive to invest}

Dating to the work of Harberger (1962), the corporation tax was viewed as an extra tax imposed on the investment returns generated by the corporate sector, with personal income taxes applied to both corporate and non-corporate investment. From this perspective, reducing the tax burden on corporate source income, either through a reduction in the corporate tax rate or through a reduction in investor-level taxes on corporate source income, would improve the economy-wide allocation of capital. Indeed, policies such as the UK imputation system were structured to reduce the double taxation of corporate-source income.

Since the Meade report, there have been several challenges to the argument for alleviating double taxation. Miller (1977) hypothesized an equilibrium in which investment financed by corporate equity faced no extra tax when compared to debt-financed investment or non-corporate investment, as a result of the interaction of progressive individual taxation and the favourable tax treatment of equity at the investor level (due to lighter and deferred taxation of capital gains). For individuals in sufficiently high personal tax brackets, Miller argued, the tax gain at the individual level would just offset the extra tax at the corporate level. If only individuals with such a tax preference for equity held shares, then the corporate tax would impose no extra tax on corporate investment, but indeed would reduce the overall tax on the returns of high-bracket investors. Thus, reducing the corporate tax would favour the corporate sector even more, as would reducing individual taxes on corporate source income. Although actual shareholding patterns do not follow the market segmentation envisioned by Miller, diversification can be understood as a balancing of tax incentives and portfolio choice that does not fully undercut Miller’s argument (Auerbach and King 1983).

Another line of reasoning, complementary to Miller's, suggests that the tax burden on equity investment is lower than would be implied by simply averaging of the tax rates on dividends and capital gains. Following an argument by King (1974), developed further in Auerbach (1979) and 
Bradford (1981), equity funds acquired through the retention of earnings should, under certain assumptions, have a before-tax cost unaffected by the tax rate on dividends; the logic is that because dividend taxes are avoided when earnings are retained, subsequent dividend taxes are merely deferred payment of the dividend taxes avoided initially, not additional taxes investment earnings. This logic suggested that reducing taxes on dividends, either directly or, for example, through an imputation system, should have no impact on investment incentives except to the extent that firms issue new equity. While various empirical tests have not definitively resolved its significance in explaining the investment behaviour and valuation of corporations ${ }^{15}$, this "new view" of equity finance clearly emphasizes the distinction between ongoing equity finance through retentions and the initial capitalization of corporate enterprises, a distinction laid out, for example, by Sinn (1991) in a model integrating the capitalization and subsequent growth of a firm subject to taxes on corporate earnings and dividends. We will return to this distinction between capitalization and investment when discussing the choice of organizational form.

A related point is the relevance of corporate cash flow to the investment decision. Among firms facing a lower cost of capital when financing through retentions, there will be a positive relationship between investment and the level of internal funds, for some investments will be worth undertaking only if adequate internal funds are available. This relationship, which has found some support in the empirical literature since the writing of the Meade report ${ }^{16}$, may also be a consequence of asymmetric information: if managers are unable to reveal their firms' true prospects to capital markets, then the act of seeking external funds may convey a negative signal about a firm and raise its cost of capital. Whatever the reason for its existence, a link between internal funds and investment makes after-tax cash flow relevant to a firm's investment. Thus, traditional calculations of the cost of capital and marginal effective tax rates based on discounted tax provisions may only partially measure the impact of these tax provisions on the incentive to invest - the timing of these provisions will matter, too.

\footnotetext{
${ }^{15}$ See Auerbach (2002) and Auerbach and Hassett (2007) for recent reviews of the relevant literature.

${ }^{16}$ The paper by Fazzari, Hubbard, and Petersen (1988) is notable here, although some (e.g., Cummins, Hassett and Oliner 2006) have argued that cash flow is simply acting as a proxy for firm prospects that are difficult to measure directly.
} 


\subsubsection{Personal taxes and the multinational enterprise}

In a closed economy, savings equals investment and it does not matter on which side of the market for funds taxes are imposed, assuming that the taxes on each side would have the same structural form. The previous arguments have suggested that the structure of individual taxes on corporate-source income serves to mitigate the impact of double-taxation. Progressive individual taxes combined with favourable treatment of capital gains plus the taxation of dividends when they are distributed (rather than when corporate earnings accrue) each contribute to a lower tax burden on the income from new corporate investment. But this analysis does not hinge on the fact that the taxes in question are assessed on investors rather than on companies. In an open economy, though, taxes on saving and investment may not have comparable effects, even if they are similar in structure, and as a result there is an additional reason why investor-level taxes may have little impact on the incentives for investment.

The tax treatment of multinational enterprises is an extremely complex subject, touched on above and treated more fully in the chapter in this volume by Griffith, Hines, and Sørensen. However, if one thinks of the taxation of companies as being largely done at source, and the taxation of investors as being based on residence, then the openness of the UK economy to capital flows increases the impact of company-level taxation on domestic investment, for such investment must compete for mobile capital with investment projects in other countries. The taxation of individual UK investors on their portfolio income, on the other hand, should have relatively little impact on UK investment, for UK investors are only one possible source of funds

for domestic enterprises and other investors will jump in to take advantage of potentially higher returns should individual tax provisions discourage UK investors.

The strength of this reasoning depends on the extent to which the well-known "home bias" in the portfolio choice of investors is overcome. If individuals invest primarily in their own countries, regardless of the tax incentives for investing abroad, then such tax incentives can have little impact. Such home bias has certainly been evident historically in the close relationship between domestic saving and investment (e.g., Feldstein and Horioka 1980) as well as in the weak international diversification of individual portfolios. But such diversification has been on the rise over time. As Figure 7 shows, around a third of UK listed shares are now held by foreign investors, compared to around 5\% when the Meade report appeared. 
Figure 7. Ownership of UK listed shares by Rest of the World

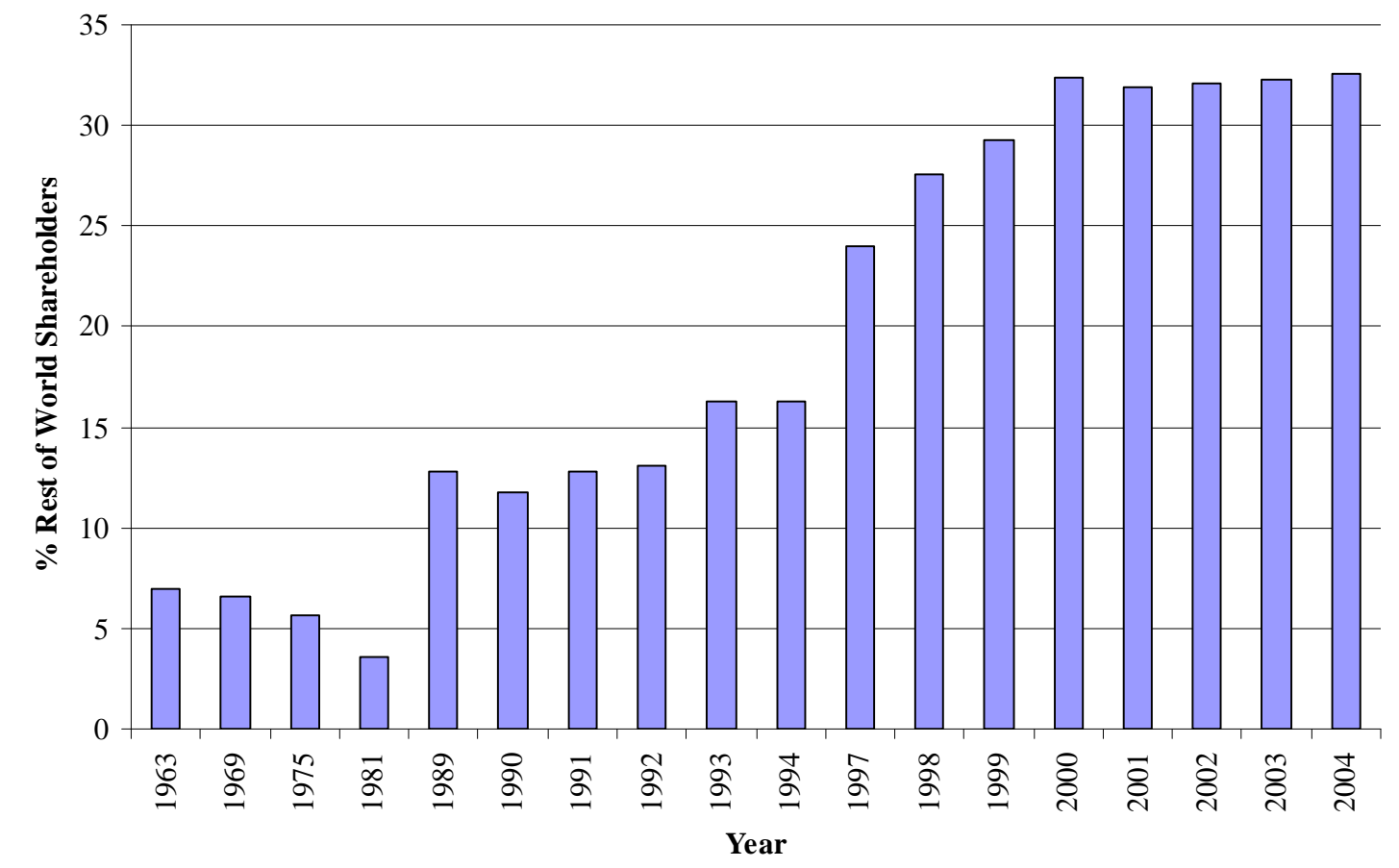

Note: Figure shows \% of UK listed ordinary shares owned by Rest of World. UK offshore islands were re-classified to RoW in 1997

Source: ONS, Share Ownership 2004.

Thus, the rise in international capital flows provides yet another reason why individual taxes may have less influence than once believed on the level of domestic corporate investment. There is a distinction here, though, in that higher taxes on the portfolios of domestic individuals may still have a considerable impact on national saving, depending on how responsive saving is to capital income taxation.

\subsubsection{Taxes and the choice of organizational form}

As discussed above, it is important to distinguish the effects of taxation on existing companies and new ones. While existing corporations may finance their expansions through retained earnings, new corporations must establish an equity base and may face a higher cost of capital as a result. As a consequence, the decision to start a corporation may be discouraged more than the decision to invest, once incorporated. If there is a choice of organizational form, this decision may be affected by corporate taxation. 
Put slightly differently, one needs to distinguish how taxation affects the intensive decisions of companies - how much to invest, given their organizational form - and the extensive decisions of companies - which organizational form to adopt. Just as in the case of the international location decision, the choice regarding organizational form depends on more than the treatment of marginal investment projects by existing companies whose locations are already determined.

It is customary to think of the choice of organizational form as one unlikely to be strongly affected by taxation, because corporate status, with its limited liability and access to capital markets, is viewed as a sine qua non for large public companies that seek broad ownership. Indeed, in the UK there are no perfect substitutes for corporate status outside the corporate sector. But elsewhere, particularly in the United States, there are ranges of organizational forms that, while not perfect substitutes, offer attributes sufficiently similar to those of traditional corporations to make the choice of organizational form a serious one.

Figure 8 shows the share of US non-financial corporate income accounted for by "S" corporations, the most important alternative to traditional corporations. S corporations have legal corporate status but are taxed as “pass-through” entities. Though an option only for companies with one class of stock and no more than one hundred shareholders, S corporations nevertheless now account for a significant part of corporate ownership. The upward jump in 1987 is consistent with incentives in the Tax Reform Act of 1986, the transition to S corporation status largest among the smaller companies most likely to view this as viable (Auerbach and Slemrod 1997). But the subsequent growth in S corporation elections may be due to a variety of factors including shifts in company size and industrial composition, and the literature to date (Gordon and Mackie-Mason 1997, Goolsbee 1998) suggests relatively modest behavioural responses to tax incentives, and hence small deadweight losses, surrounding the choice of organizational form. 


\section{Figure 8. S Corporation Share of U.S. Non-financial Corporate Income}

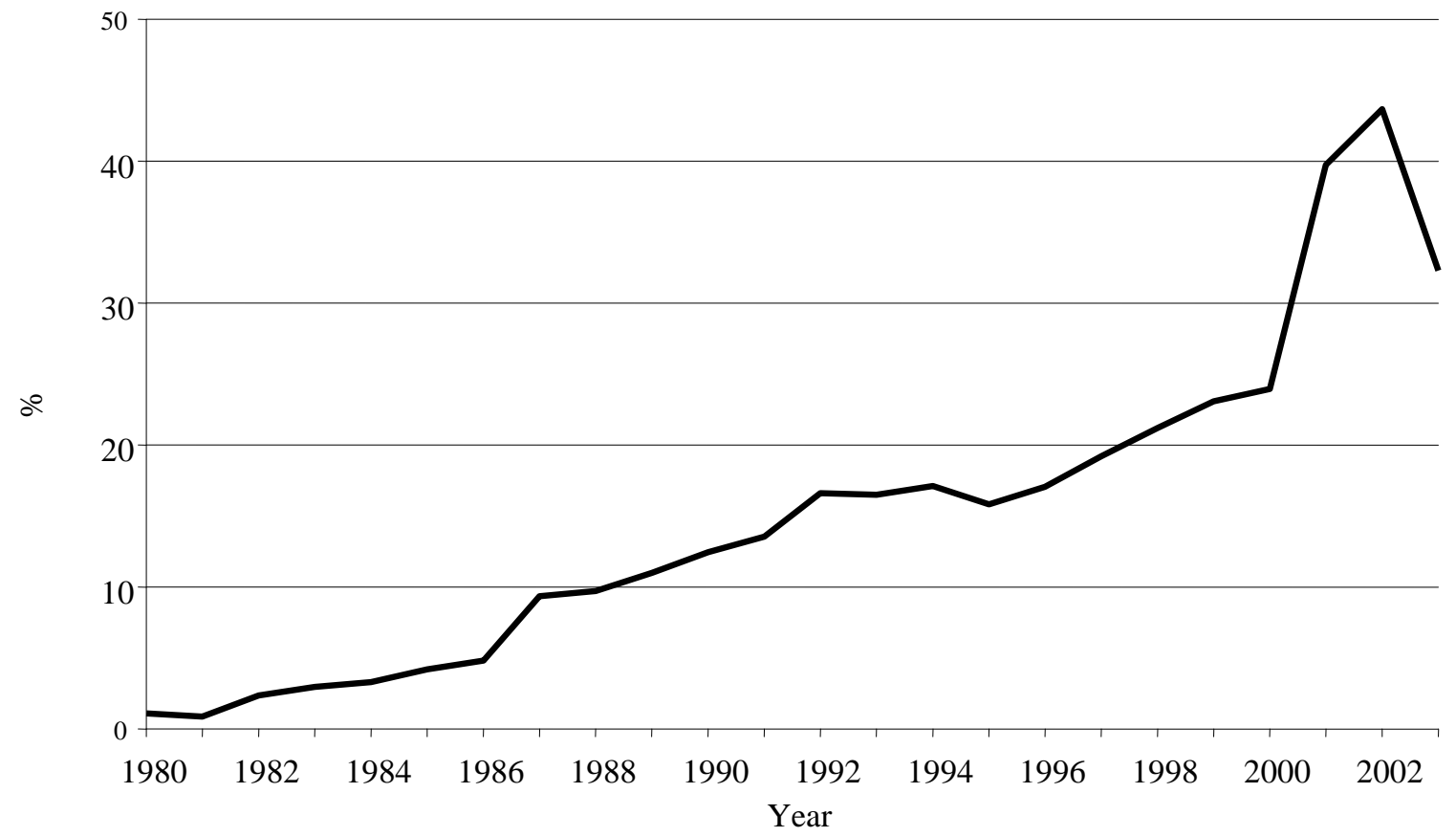

Source: Internal Revenue Service, Statistics of Income

\subsubsection{Implications for Tax Reform}

A recurring theme in the discussion of the interaction of personal and corporate taxes is the importance of heterogeneity. Individuals sorting by tax rates may reduce the combined impact of corporate and individual taxes; firms financing with retained earnings may face a lower cost of capital than is faced by new corporations; individual taxes may influence the cost of capital more for domestic companies that rely solely on domestic investors as a source of funds than for those capitalized internationally; and smaller firms with simpler ownership structures may have a greater ability to avoid the traditional corporate form if it is advantageous from a tax perspective to do so.

This heterogeneity in behavioural responses suggests a need for flexibility in the design of tax reforms not emphasized in the Meade report, to allow treatment to vary among firms and individuals according to circumstances. We might wish to treat domestic companies differently from multinational companies, new companies differently from existing ones, and small 
companies differently from large ones, ${ }^{17}$ and we might wish to vary the extent of double-taxation relief among individual investors.

\section{Optimal properties of corporation taxes}

This section discusses what the aims of a corporation tax should be in closed and open economies. In open economies, one must distinguish between the perspectives of a country acting unilaterally and one acting in coordination with other countries.

The first and most important question to address is "Why corporate taxes?" To the extent that corporate taxes play a role that could be occupied by taxes on individuals, why tax corporations at all? From a positive perspective, corporate taxes may exist in part because of the political advantage of imposing taxes the burdens of which are difficult to trace through to individuals. But there are also several potential normative justifications for taxing corporations.

First, corporations may offer an easier point of tax collection, even if the aim is to impose a tax on individuals. It may be easier, for example, to impose a tax on consumption using a tax on corporate cash flows rather than a personal consumption tax. Second, the base of taxation may be most easily measured at the corporate level. For example, if the aim is to tax rents generated by corporate activities, there is no advantage in tracing the receipt of these rents to individuals rather than taxing them directly. Third, taxing corporations may expand the scope of possible tax bases. If a country wishes to tax foreign shareholders of domestic corporations, for example, this may be legally possible and administratively feasible only through a tax on the corporations directly.

Thus, there may be a role for taxes on corporations, but the role will depend on the characteristics of the optimal tax system. For example, if there is no benefit to taxing foreign shareholders, then there will be no advantage to imposing taxes on domestic corporations in order to do so. Thus, we must first lay out the characteristics of a desired tax system before assessing the advantages of particular forms of corporate taxation. We begin by considering the simpler case of the closed economy, in which there is no issue of international coordination and taxes on saving and investment have equivalent effects.

\footnotetext{
${ }^{17}$ Crawford and Freedman (this volume) deal with the particular issues of designing tax regimes for small companies.
} 
Since Meade a literature has developed on the optimal tax rate on capital income in a closed economy. Various celebrated papers, beginning with Judd (1985) and Chamley (1986), argue that the optimal capital income tax rate in a dynamic setting is zero, though others find conditions under which it is positive. A second strand of the literature has emphasized the dispersions in effective tax rates that typically accompany capital income taxation and the distortions associated with this differential taxation. ${ }^{18}$ Although the message of this literature reinforces arguments against a classical corporate tax system, it is consistent with the Meade approach of aiming for a zero effective marginal tax rate on corporate source income. Such a tax falls on projects which earn an economic rent, and on old capital (which has not received cash flow treatment of expenses). In a closed economy, taxes on rents are non-distortionary, as are taxes on old capital, to the extent that such taxes are not anticipated. Thus, there is an argument for imposing corporate taxes in a closed economy even if capital income taxes are not desirable. To the extent that capital income taxes remain part of the optimal tax system, corporate taxes can play a role as a collection mechanism, although the additional distortions associated with corporate taxation, discussed in section 4 , must be taken into account.

In an open economy, one must be more specific regarding the manner in which capital income taxes are imposed. Where it may be optimal to distort the saving decisions of residents, a country may wish to impose residence-based capital income taxes. But the literature, starting from the production efficiency theorem of Diamond and Mirrlees (1971) and developed in various contexts in the years since the Meade report, suggests that small open economies should eschew source-based capital income taxation. Such a tax simply raises the pre-tax required rate of return and reduces the stock of capital, shifting none of the burden to foreigners but resulting in more deadweight loss than a tax on the domestic factors that bear the tax. Just as source-based capital taxes should be avoided, the returns from outbound investment by residents should be taxed at the same rate as their returns on domestic investment; foreign taxes should be treated as an expense. This is a direct implication of imposing taxes on a residence basis.

These results, however, hold exactly only for small open economies acting unilaterally. Moreover, they apply to taxes on individual residents, where such residence is taken as given.

\footnotetext{
${ }^{18}$ See, for example, King and Fullerton (1984) and Auerbach (1983).
} 
When one shifts to a consideration of corporate taxes, the picture becomes cloudy, because a corporation's residence may differ from that of its shareholders and may also be much more easily adjusted in response to taxation. To the extent that corporations are internationally mobile, taxes based on corporate residence may have undesired effects similar to taxes based on source. Thus, the distinction between source-based and residence-based taxes is less clear for corporate income taxes than for taxes on individuals, and residence-based taxes are less obviously superior.

Open-economy considerations also affect what it takes to accomplish a zero rate on business activities. While the Meade flow-of-funds tax would accomplish this objective in a domesticonly context, the discrete location and profit shifting possibilities imply that a small open economy might wish to have a zero tax rate on average returns and on moveable profits, an outcome possible only by eliminating source-based taxes entirely. In this case, source-based taxes might be justified only to the extent that there are location-specific economic rents, though such taxes might still be unattractive if they had to apply economy-wide.

If small open countries coordinate, then the range of polices expands. Coordinated source-based taxation, for example, could serve as a substitute for residence-based taxation if the latter approach were not feasible, although to an extent limited by different national revenue objectives and constraints. Hence, the role for source-based taxes may be stronger than for the small open economy acting on its own.

The most complex open-economy analysis applies to the choices made by a country for which the small-economy assumption does not hold. For such countries acting unilaterally, tax polices that serve the national interest need not further the objective of economic efficiency. Just as the optimal tariff for a large country is positive, the optimal source-based capital income tax is positive, for each action improves the country's terms of trade with the rest of the world. This strengthens the argument for policy coordination, which is also more difficult to analyze because of the variety of equilibrium concepts applicable when large countries interact.

\section{Alternative tax systems}

This section considers a number of potential tax systems in the light of sections 4 and 5 drawing on the organisation of Table 1. The two broad questions to be considered are: what should be 
taxed, and where should it be taxed? Each of the subsections below investigates options within a specific type of location: source, residence and destination.

\subsection{Source-based taxation}

We begin with source-based taxation, on the grounds that this is the conventional approach to taxing corporations. However, in addition to the question considered above, whether it is desirable to tax corporate income at source, there is also a definitional problem that affects source-based taxation, whether applied to income or some other base. Attempting to define the "source" of profit is actually very difficult, and in some cases impossible. We can begin with a simple example. Consider an individual resident in country A who wholly owns a company which is registered, and which carries out all its activities - employment, production, sales - in country B. Then country B is clearly the source country. In this simple example, country A is the “residence” country. Conventionally, we can also drop sales from the list of activities in B. Suppose that the company exports all of its output to country C: then country B remains the source country. We refer to country C as the "destination” country.

Now add a holding company in country D; so that our individual owns the shares in the holding company, which in turn owns the shares in the subsidiary located in B. Typically D would be thought of as a form of residence country as well: the residence of the multinational group. But in practice that may depend the activities undertaken in D: typically, it would be seen as the place of residence only if management and control were exercised from D.

Returning to the source country, things rapidly become less simple. Suppose instead that this multinational has also two R\&D laboratories in countries E and F, a subsidiary which provides finance in $G$, with the final product marketed by another subsidiary in H. Each of these activities is a necessary part of the whole which generates worldwide profit. There are now potentially five source countries: B, E, F, G and H. A conventional definition of "source" would require the contribution made by each subsidiary to worldwide profit to be calculated, with these contributions determined using “arm's length pricing” - the price that would be charged by each subsidiary for its services were it dealing with an unrelated party. Of course, this procedure is difficult in practice since in many cases no such arm's length price can be observed; transactions between subsidiaries of the same corporation are not replicated between third parties. 
But there is also a more fundamental problem with this approach: the arm's length price may not exist even conceptually. As an example, suppose that each R\&D laboratory has invented, and patented, a crucial element of the production technology. Each patent is worthless without the other. One measure of the arms length price of each patent is therefore clearly zero - a third party would not be prepared to pay anything for a single patent. Another possible measure would be to identify the arm's length price of one patent if the purchaser already owned the other patent. But if both patents were valued in this way, then their total value could easily be larger than the value of the final output. More generally, suppose that this multinational is a monopolist supplier of the final good. Then not only are there no other actual potential purchasers of the patents, but if there were, then the value of the patents would be different (and generally lower, as more competition is introduced in the industry).

So identifying how profit is allocated on a source basis between countries B, E, F, G and H is not only extremely difficult in practice; there are clearly examples where it is conceptually meaningless. This is a fundamental problem of any source-based tax. Although it is a problem with which the world has long since learned to live, allocating profit among source countries is in practice a source of great complexity and uncertainty. Having raised this issue, though, we will now consider specific forms of source country taxation, identifying more specific tax bases.

\subsubsection{Standard corporation tax, on the return to equity}

We begin with the most common form of corporate income taxation, which exists in the vast majority of developed countries: a source-based tax levied on the return to equity. Income is allocated between source countries on the basis of arm's length pricing.

The inefficiencies introduced by such a tax are well known, and have been largely outlined above. Because relief is given for debt finance, but not equity finance, it generates an incentive to use financial instruments which, for tax purposes at least, have the form of debt. In an international context, this creates an incentive to borrow in high-tax-rate jurisdictions (and lend to them from low-tax-rate jurisdictions), although governments try to limit this through the use of thin capitalisation and interest allocation rules (which in turn generate further distortions). The welfare costs associated with these distortions are, however, hard to pin down. Ultimately, greater use of debt is likely to generate higher levels of insolvency and bankruptcy. That 
generates direct costs of bankruptcy, and also possibly indirect costs in terms of the effect on competition in specific markets. The costs of the industry which exists to exploit these differential effects also represent a welfare cost; though ironically, the more successful this industry is in creating financial instruments which are effectively equity, but are treated for tax purposes as debt, the lower will be tax-induced bankruptcy. The welfare costs of shifting profits between jurisdictions to reduce the overall tax liability are also hard to value, as the technology of profit-shifting is difficult to specify.

A standard source-based income tax also affects the location and scale of investment, as discussed in Section 4.1. As reviewed in Section 5, standard analysis indicates that a small open economy should not have a sourced-based tax on the return to capital located there. If there are economic rents that are specific to a particular location, it may in principle be possible for the government to capture those rents through taxation without inducing capital to shift out of the country. However, this is more a justification for a flow of funds tax, discussed below, since that is structured to tax economic rent but not the return to capital. In any case, more realistically, it seems infeasible to design a tax system which captures only location-specific rents. It may be possible to have a tax system which captures part of all economic rents, but this creates a tradeoff between capturing the location-specific rent, and inducing some capital and mobile rents to flow abroad. ${ }^{19}$

\subsubsection{Formula apportionment}

One approach to dealing with the difficulty of determining the source of income is to allocate income to countries using measurable quantities that are viewed as proxies for income generating activities. This approach, referred to as formula apportionment, is practiced by US states in determining state corporate tax liabilities and has been proposed for the EU as well. Under formula apportionment, the world-wide (or, in the case of US states, domestic US) income of a company operating across boundaries are divided according to a simple formula based on the fractions of measured activities located in each jurisdiction; many US states use a three-

\footnotetext{
${ }^{19}$ From an international perspective, Keen and Piekkola (1997) also show that if governments cannot fully tax away economic rent, then it is in principle optimal to allow capital-importing countries to use source-based taxes as an indirect way of taxing pure rents.
} 
factor formula that assigns equal weights to shares of assets, payroll and sales in the jurisdiction, although some states assign greater, even total, weight to the sales factor.

Within a group of jurisdictions that agreed to adopt a system of formula apportionment, the calculation of income for any source jurisdiction would be simplified, and profit-shifting under source-based taxation would be reduced, since the location of profits would be determined by formula rather than by accounting and financial arrangements. Even within this group, though, formula apportionment would not eliminate the incentive to shift capital out of a high-tax jurisdiction, as long as assets are a factor in assignment of income among jurisdiction. The exact incentives faced by individual companies would depend on the extent to which policies were coordinated among countries. ${ }^{20}$ Such coordination would potentially relate not only to the apportionment formula but also to the base used to determine taxable income. Absent policy coordination with respect to base and apportionment formula, governments would have incentives to compete in these dimensions. With a uniform tax base and apportionment formula, the incentive to engage in tax competition with respect to the choice of tax rates may even be strengthened. While differences in tax bases remain, the impact of differences in the tax rate may be uncertain, or at least more difficult to discern. If tax bases were uniform, the impact of the tax rate is much clearer. Further, since countries would no longer be able to compete over the tax base, all competition would take place through the tax rate.

The European Commission has proposed a form of formula apportionment within the EU. This is subject to the advantages and disadvantages described. But in addition, it should be noted that the problems of source-based taxation remain if there is a boundary to the region in which formula apportionment applies - that is, with respect to any transactions between the group of jurisdictions with formula apportionment and the rest of the world. This is why we discuss formula apportionment in the context of a source-based tax: its main effect is not to eliminate the problem of defining source-based taxation, but simply to extend the boundaries over which source-based taxable income is computed.

\footnotetext{
20 See McLure (1980) and Gordon and Wilson (1986) for a discussion of the effects of formula apportionment of business location decisions.
} 


\subsubsection{Corporate flow-of-funds tax}

The Meade Committee proposed two flow-of-funds taxes - the R base and the R+F (equivalently the S) base - which were designed to remove two distortions present in the standard corporation taxes summarised above: they do not affect decisions as to the scale of investment, and they do not discriminate between investment financed by different sources of finance. As noted above, they achieve this by leaving a marginal investment (one with a zero net present value) untaxed. The tax effectively is raised only on economic rent - that is, projects with a positive net present value.

As noted above, though, a source-based flow-of-funds tax leaves some distortions in place, in particular with respect to two important location decisions. Companies making discrete location choices will normally consider alternative locations on the basis of a comparison of the post-tax net present value. In general this would be affected by a flow-of-funds tax. Also, the question of the location of the "source" of the profit is not resolved by a "source-based" flow-of-funds tax. Indeed, the incentives to shift profit may be greater under a flow-of-funds tax to the extent to which a revenue-neutral reform which introduced a flow-of-funds tax would require a higher statutory tax rate (this is discussed further below). In turn, this would create greater incentives for shifting profits between jurisdictions. It may also induce the most profitable firms to move abroad, leaving the domestic economy with the less profitable firms. ${ }^{21}$

Three further well-known problems should also be mentioned. The first concerns transition effects. If introduced without an appropriate phasing in period (which could be very long), then existing capital would be more heavily taxed than new investment. To some extent that might be regarded as efficient, if inequitable. However, treating competing companies unequally might introduce distortions to competition and hence welfare costs, for example, if companies face financial constraints on their activities.

Second, the neutrality of the tax with respect to investment depends crucially on the tax rate being constant over time: indeed, it requires that investors believe that the tax rate will not change in the future. If investors expect future returns to be taxed at a different rate than current investment is relieved, then marginal investments will be taxed (or subsidised). However, this is

\footnotetext{
${ }^{21}$ See Bond (2000).
} 
not only true for flow-of-funds taxes: no realistic tax can be neutral with respect to the scale of investment if the tax rate is expected to fluctuate. ${ }^{22}$

Third, a pure flow-of-funds tax requires the tax to be symmetric: tax payments must be negative when there are taxable losses. For a conventional investment, which involves initial capital expenditure, followed subsequently by a return, this implies that the initial investment is effectively subsidised. Governments are typically reluctant to provide such subsidies, especially through a general tax system - and with some reason, since they would enhance the possibility of fraud. The next form of tax we consider is designed to lessen this problem.

We also raise one further question, which applies to this form of tax along with others considered here (and which was also addressed by the Meade Committee): would the international tax treaty system create problems for a single country introducing this form of tax on its own? The basic advantage of the flow of funds tax - the zero effective marginal tax rate applies only if there is no other tax levied on the income stream from the investment. But for inbound investment, the capital-exporting "residence" country may seek to tax the remittance of profit. Under existing tax treaties, any such residence-based tax would normally be moderated by a credit for tax already paid in the source country. If such a credit were given in respect of the flow of funds tax as well, then the residence-based tax would affect the overall effective average and marginal tax rates on such inbound investment, but these effects would not be too large as long as the statutory rates in the two countries were similar. However, if the capital-exporting country refused to give a credit for the flow of funds tax, then the overall effective average and marginal tax rates on inbound investment could be very large, reflecting both source- and residence-based taxation. Such a situation could substantially diminish or remove the benefits from reforming the tax in this way, at least with respect to inbound investment from such capitalexporting countries.

\footnotetext{
${ }^{22}$ See Bond and Devereux (1995).
} 


\subsubsection{Revenue consequences of a flow of funds tax}

In this paper we do not provide a costing of alternative reforms to the taxation of corporate income. However, since an important focus of discussion is on the flow of funds tax, on a source (and below) destination basis, it is worth making some brief comments.

First, an important element of the cost in terms of tax revenue concerns the treatment of existing capital. On introduction of a flow of funds tax for new investment, the remaining value of such existing capital could be immediately expensed, or alternatively, it could be depreciated as under the existing system or simply denied depreciation deductions entirely. ${ }^{23}$ We have noted above the efficiency issues surrounding this distinction; but there are clearly revenue implications as well. The same issue arises with respect to outstanding debt: would interest on such debt continue to be deductible for tax? These choices would clearly be very important for revenues for a lengthy transition period. A second factor likely to be important is the treatment of financial services: there may be significant differences in revenue from an R-base compared to an $\mathrm{R}+\mathrm{F}$ base. A third issue is that we would expect the introduction of a flow of funds tax to have behavioural effects: to provide a complete measure of the revenue consequences of reform it would be necessary to take into account these effects.

One way of attempting to identify the broad revenue effects of moving to a flow of funds base is to identify the various components of the existing tax and estimate how they would change. Consider a move to an R-base, for example. Then the most significant effects would be that (i) depreciation allowances would be abolished and replaced by immediate expensing, and (ii) deductibility of nominal interest payments would be abolished. The first of these would tend to reduce revenues, while the second would tend to raise revenues. So, as a matter of principle, it is not clear in which direction revenues would move. It is clear that the reform would be less costly the lower is investment, the higher are nominal interest rates (and hence the inflation rate), and the more that companies use debt. More generally, we might expect the cost of such a reform to depend on when it was introduced, and to vary over time depending on broad economic conditions. As a result of these considerations, we do not propose to present our own estimates of the cost of introducing such a reform at any point in time. 
However, we can get some idea of the cost from a recent study carried out using US data by Gordon, Kalambokidis and Slemrod (2004), which draws on an earlier paper by Gordon and Slemrod (1988). They estimate the cost of introducing a source-based R-base tax in the US in two years, 1983 and 1995, following the procedure described above of identifying changes to particular elements of the tax base in each year. They found that introducing the change in 1983 would have increased tax liabilities of nonfinancial corporations by $\$ 23$ billion (of which $\$ 14$ billion was accounted for by eliminating the investment tax credit), or by more than half of the actual tax liabilities of these corporations, whereas introducing the change in 1995 would have reduced tax liabilities by $\$ 18$ billion, or by $16.3 \%$ of actual tax liabilities. Several factors account for the difference between the two years, notably that the investment tax credit was repealed in 1986 and the ratio of interest payments to new investment fell from 37\% in 1983 to only 20\% in 1995. The authors also attempt to control for these and other business cycle effects to make the two years more comparable: the adjustment has little impact in 1983, but reduces the cost in 1995 to approximately zero. Although the costs of implementing an R-base in the UK may clearly differ, these estimates suggest that they may not be very large.

\subsubsection{Allowance for corporate equity}

A variant of the flow-of-funds tax was initially proposed by Boadway and Bruce (1982) and developed by IFS (1991). There are two possible versions. One is closest to the R-base: it would eliminate the deduction for interest and, instead of giving up-front relief for all investment expenditure, would use an arbitrary depreciation schedule but exactly compensate for the delay in receiving depreciation allowances by giving additional relief. A version closer to the $\mathrm{R}+\mathrm{F}$ base would be to continue to allow interest to be deducted, but would introduce a separate allowance for the cost of equity finance (the Allowance for Corporate Equity, ACE). The size of the ACE allowance is designed to compensate exactly for the delay receiving depreciation allowances. In each case, in an uncertain environment the rate of relief required for neutrality is the risk-free rate, as long as the relief is certain to be received by the company at some point. ${ }^{24}$ Various forms

\footnotetext{
${ }^{23}$ In this case there would need to be anti-avoidance rules to prevent "old” capital becoming "new" and hence qualifying for immediate expensing.

${ }^{24}$ See Bond and Devereux (1995, 2003).
} 
of the ACE tax have been used: Croatia has experimented with it, and Belgium has recently introduced it. Brazil and Italy have also used variants.

Either variant of the ACE system avoids the government's problem under the pure flow-of-funds tax of paying a proportion of up-front investment costs. Given that the timing difference between receiving relief and paying tax on the return is reduced, the ACE system also lessens (although likely does not remove entirely) the sensitivity of investment to tax-rate changes. It is also more likely - though not certain - that capital-exporting countries would be prepared give a tax credit for the ACE than for a flow of funds tax, since the ACE more closely resembles a conventional corporate income tax. However, all other criticisms of source-based flow-of-funds taxes also apply to these variants. ${ }^{25}$

\subsubsection{Comprehensive Business Income Tax}

The differential treatment of debt and equity can be eliminated in two ways. One is to give equity the same treatment as debt - this is essentially the route taken by the ACE system, and which results in a tax only on economic rent. The other is a reform in the opposite direction: to remove the deductibility of interest from taxable income. This was proposed by the US Treasury (1992), and is called the Comprehensive Business Income Tax (CBIT). The CBIT results in a single tax on all corporate income, whether the source of finance is debt or equity.

The original proposal envisaged it would be introduced at a rate roughly equal to the top marginal personal tax rate on capital income. This would in principle make personal taxes on corporate source income redundant, at least in a closed economy. Other things being equal, corporate taxable income would be higher under a CBIT than a conventional tax. Offsetting this, however, would be a reduction in personal taxes on corporate source income if such taxes were abolished. In fact, probably a large proportion of interest income is untaxed - for example, if it is received by tax exempt pension funds. Overall, a revenue neutral reform would therefore enable

\footnotetext{
${ }^{25}$ If the corporation tax is based on economic rent, there is a question as to the appropriate personal taxation of income from the corporation. The Meade Committee and IFS (1991) envisaged a tax on economic rent at the corporate level being introduced in combination with different forms of consumption tax treatment at the personal level, so that the overall marginal tax rate on savings was zero. An alternative approach would be to combine a corporate tax on economic rent with a residence-based individual tax on the normal return, as proposed recently by Kleinbard (2007).
} 
a cut in the statutory corporation tax rate (although this may imply a significantly lower rate than the top marginal personal income tax rate).

Assuming that there were such a cut, then the effective tax rate on equity-financed investment would generally fall, and the effective tax rate on debt-financed investment would generally rise, relative a standard corporation tax. The net effect would be to reduce distortions to the scale and location of equity-financed investment, but to increase the distortions to the scale and location of debt-financed investment (assuming that the debt is issued and deductible in the same country as the investment). A lower tax rate will probably have a greater net impact on the effective average rate of tax, and hence on location decisions. The lower tax rate would also reduce the incentives to shift profit at the margin to another jurisdiction.

There would of course be transitional problems in moving to a CBIT: companies relying heavily on debt would be significantly disadvantaged by such a reform. Any such reform would therefore have to be phased in slowly to give companies time to adjust their financial position.

\subsubsection{Dual income tax}

A variant of the CBIT is the dual income tax, which is used in some Scandinavian countries. ${ }^{26}$ The basic idea of a dual income tax is to have a low tax rate on all capital income, while keeping a progressive labour income tax. If the dual income tax were imposed solely at the corporate level, then it would have exactly the same structure as the CBIT.

However, the original proposals differ in the tax rate which they envisage on capital income. Tying the CBIT rate to the highest rate of personal income tax has the advantage of minimising distortions to organisational form: businesses would be indifferent to paying income tax or a CBIT corporation tax. However, a high tax rate is likely to discourage inward flows of capital and profit. By contrast, proponents of the dual income tax point to the need to encourage inward international capital flows as a reason for keeping a low tax rate on capital income. In a pure version of the system, the corporate income tax rate is matched to the lowest marginal personal income tax rate so that only labour income above a certain level is taxed at a higher rate. That though, raises the problem of distortions to organisational form: an owner-manager would rather

\footnotetext{
${ }^{26}$ See Sørensen (1994, 2005a) and Nielsen and Sørensen (1997).
} 
take his return in the form of capital income than labour income. ${ }^{27}$ (Although this problem is not unique to the dual income tax; it applies whenever capital income and labour income are taxed at different rates).

A further difference from the CBIT is an important distinction in implementation. Instead of levying a single tax rate on all corporate income, dual income taxes tend to give relief for interest paid at the corporate level, as with a conventional corporation tax, and instead tax it at the personal level, possibly using a withholding tax, typically set at a lower for non-residents. However, this means that interest paid to non-residents is typically taxed at a lower rate than interest paid to residents. That reintroduces a distinction between debt and equity which is avoided under the CBIT.

\subsection{Residence-based taxation}

In general, identifying a residence country is more straightforward than identifying a source country. However, unfortunately this does not imply that residence-based taxes would be more straightforward to administer. There are two possible forms of residence: the residence of the ultimate individual shareholder, and the residence of the legal corporation. We discuss these in turn.

\subsubsection{Residence-based shareholder tax on accrued worldwide profit}

Although the legal residence of some individuals may be open to debate, for the vast majority of individuals, their country of residence is easy to identify. Moreover, the vast majority of individuals remain relatively immobile. Levying a tax on corporate source income at the level of the individual shareholder therefore has important conceptual advantages. In particular, since the tax base would not depend on where capital or profit were located (i.e. where the source country is), then the location of capital and profit would not be distorted by this tax.

Moreover, the effective incidence of a residence-based tax can be expected to be quite different from a source-based tax. A tax levied on the residents of a small open economy country will

\footnotetext{
${ }^{27}$ To prevent such income shifting, Norway has introduced a personal residence-based tax on that part of the taxpayer's realized income from shares which exceeds an imputed rate of interest. This is in principle neutral, since it exempts the normal return from tax. At the margin, the total corporate and personal tax burden on corporate equity income is close to the top marginal tax rate on labour income. See Sorensen (2005b).
} 
reduce the post-tax rate of return they earn on world markets: it will not affect the pre-tax rates of return. Hence the effective incidence of the tax would be on the investors. As discussed in Section 5, this is what underlies the economic argument favouring residence-based taxes over source-based taxes for small open economies.

Such a tax, in its pure form, is unworkable. Any individual country would be seeking to tax corporate income accruing to its residents from throughout the world; either the company or the shareholder would have to provide details of that income. The government would have no jurisdiction over companies which were otherwise unconnected with that country. The shareholder might own shares in a large number of companies worldwide: it would be extremely costly to collect and provide detailed information on all of them. For companies which the investor continued to hold, it would be necessary to identify the portion of the profit generated, and a tax return based on the home government's taxable income definitions would need to be drawn up. For companies which the investor had sold, it would be necessary to identify dividends and capital gains earned during the period in which shares were held.

There would also be a problem of liquidity: it might be necessary to sell part of the asset in order to meet the tax liability. Of course, some of these problems would be eased if the tax were levied only on income received from foreign investments: but that would be a very different tax, which could be avoided by not returning the income to the owners, but allowing the investment to accumulate abroad.

Of course, these problems exist only to the extent that UK residents have direct portfolio holdings of foreign securities. In the past, this would not have been of such great concern as international portfolio diversification lagged well behind what economists might have expected given its apparent risk-pooling advantages. But international diversification has been growing, as illustrated above in Figure 7. This limits the attractiveness of residence-based shareholder taxation as an option for the future.

\subsubsection{Residence-based corporation tax on accrued worldwide earnings}

An alternative notion of residence is the residence of the company which is the ultimate owner of a multinational. Of course, a form of residence-based corporation tax is currently common: the UK and the USA, for example, both seek to tax flows of foreign dividend income paid by foreign 
subsidiaries to parent companies. However, the notion of residence here is rather less clear-cut. To prevent tax avoidance, countries that seek to tax such income typically have rules to determine whether or not the company is resident for tax purposes; these rules are usually based on the notion of whether the multinational company is managed from that location.

The notion of residence-based corporation tax which we aim to discuss here, though, is one that taxes the worldwide earnings of the multinational as it accrues, rather than as it is repatriated to the parent company. As with a residence-based shareholder tax, taxing only repatriations may generate a strong incentive for the company to reinvest abroad, without returning retained earnings to the parent. Even when countries attempt to implement a tax on repatriations, they typically give credit for taxes paid abroad. There are various ways of giving such credit, but the net effect is that skilled tax managers can arrange the group's financial affairs to prevent significant liabilities to such home country tax. ${ }^{28}$ Thus, application of the "residence principle" to corporations, in practice, bears a strong resemblance to source-based taxation.

In principle, true residence-based corporate taxation, i.e., a residence-based, accruals-based corporation tax, has one significant advantage. The home country tax authorities need only identify the worldwide taxable income of the multinational company. There would be no need to identify "where" the profit was made; all that would matter would be the aggregate for the whole multinational. As a consequence - if all countries adopted such a tax - there would be no incentive for companies to shift profits between subsidiaries in different countries to reduce tax liabilities. Nor would the tax affect the location of capital investment.

However, there are also two significant problems with such a hypothetical corporation tax. The first is feasibility. In this respect, some of the problems of the residence-based shareholder tax are also relevant. A multinational company may have hundreds, or even thousands, of subsidiaries and branches around the world. Correctly identifying - and where necessary, checking - the taxable income in each of these locations would be challenging, even if ultimately the taxable income is consolidated into a single measure. ${ }^{29}$

\footnotetext{
${ }^{28}$ The recent US experience of a temporary reduction in such taxes provides evidence that this is partly due to simply leaving the funds abroad.

${ }^{29}$ Of course, such problems exist even under the current approach to residence-based taxation to the extent that foreign profits are taxed immediately (as is true in the US for foreign branches).
} 
Second, as discussed in Section 5, unlike shareholders, the ultimate holding company of a multinational company is, in principle, mobile. There have certainly been instances of holding companies moving location to take advantage of more favourable treatment elsewhere. ${ }^{30}$ The rules mentioned above are relevant here: the original country of residence may not recognise that the holding company has actually moved unless its management and control has moved. But the mobility of the holding company raises a question of legitimacy. Suppose there is a holding company residing in the UK which earns profit throughout the world. Suppose also that the relevant economic activity does not take place in the UK, the shareholders do not live in the UK, and the consumers of the final products do not live in the UK. What right would the UK have to tax the worldwide profit of that company? It is hard to think of a convincing rationale. And in any case, if the UK attempted to impose a high tax rate then it seems very likely that the holding company would move to another location.

In short, while true residence-based taxation, at either the individual level or the corporate level, offers potential advantages, neither system is feasible to adopt. The partial approach currently practiced in the UK, which focuses on the corporate level and lies somewhere in between residence- and source-based taxation, lacks obvious advantages other than its feasibility.

\subsection{Destination-based taxation}

In our view, there are significant problems in attempting to tax corporate income on a source basis or a residence basis. Although the international tax system is intended to be based on a combination of source- and residence-based taxation, in many cases it is not clear what "sourcebased" taxation is. What is clear is that the existing tax system creates considerable inefficiencies in the way it is implemented.

We therefore now turn to a more radical proposal: a destination-based tax. ${ }^{31}$ The term "destination-based" taxation is taken from the literature on indirect taxes, which has debated the merits of destination-based taxes, based on where the final consumer lives and purchases a good

\footnotetext{
${ }^{30}$ See, for example, Desai and Hines (2002).

${ }^{31}$ This was first proposed as a form of corporation tax by Bond and Devereux (2002), which analyses the impact of the tax on location and investment decisions, although many of the business tax issues were analysed in the broader context of consumption taxation by Grubert and Newlon $(1995,1997)$.
} 
or service, compared to an origin-based (e.g., source-based) tax, based on where the good or service is created.

\subsubsection{Corporate cash flow tax}

Given the difficulties in implementing taxes on a source or residence basis which are both feasible and non-distorting, it is worth considering whether a tax on corporate income could be levied on a destination basis. If that were possible then the tax would avoid distorting the location of capital and profit.

However, while it is clearly possible to identify final sales taking place in a country, those sales may be based on imported goods. The cost of producing those imported goods would have been borne elsewhere. A crucial issue is how costs can be set against income. Further, clearly a single plant in one country, say A, could supply final goods to a large number of other countries: how can the costs borne in A be allocated against income generated elsewhere? One option would be to take a simple formula: say to allocate costs to foreign countries in the same proportion as the value of final sales across those countries. This would effectively be a form of formula apportionment, as discussed above in the context of source-based taxes, where the formula was based only on final sales. This, and other possibilities, would require a significant degree of cooperation between tax authorities in identifying the size of costs and the value of goods sold in possibly a large number of other countries.

A more plausible alternative would be to organise the tax in the same way as a destination-based VAT. Indeed, value added as measured by VAT is equal to the sum of economic rent and labour income. In a closed economy, a VAT which also gave relief for labour costs would be equivalent to an R-based cash flow tax. All real costs, including labour costs, but not financial costs, would be deductible from the tax base. In an open economy, a destination-based VAT which also gave relief for labour costs would be a destination-based, R-based, flow-of-funds tax. Since it would be equivalent to an R-based tax, it would not affect financial policy, nor would it affect the scale of investment. And since it would be levied on a destination-basis, it would not affect the location of capital or profit.

How would such a destination-based cash flow tax allocate costs between countries? It would relieve those costs in the exporting country in which they were incurred. Just as for VAT, an 
exporting company would not be taxed on its exports (although the import would be taxed in the destination country). Any VAT a company had already paid on intermediate goods would be refunded. A destination-based cash flow tax would also need additionally to give a refund to reflect the cost of labour. A company which exported all its goods would therefore face a negative tax liability, reflecting tax relief for the cost of its labour.

On the face of it, this does not seem very feasible. Although countries would not be subsidising exports (since the export price would be unaffected), they might face negative tax payments in the case where domestic costs (including labour costs) exceed domestic sales, for example for companies which predominantly export their output. Offsetting that, of course, is the fact that they would be taxing imports. The country's overall revenue position would therefore depend on the balance of trade in any given year. However, there are administrative ways of avoiding negative tax payments, if these are seen as problematic. One is to make offsetting adjustments to other taxes, for example payroll taxes withheld: instead of paying a rebate, the amount repayable could be set against the company's other tax liability. A second approach would be to enact the tax by increasing the rate of VAT: but since this would be a tax on labour income as well as economic rent, an offsetting reduction to taxes on labour income would be needed.

It should be clear that such a combination of taxes would not distort the location of capital or profit, while an origin-based tax, without border adjustments, would. It is worth noting, however, that the economic literature on VAT has identified conditions under which a destination-based VAT and an origin-based VAT would in other respects have exactly the same real effects. This raises the question of how similar origin-based and destination-based cash flow taxes would be with respect to other real decisions. Under certain conditions, these taxes would have the similar incentive effects. These conditions include that there must be a single tax rate on all goods and no cross-border shopping or labour mobility between countries, conditions that are not met in practice. ${ }^{32}$ Further, even if these conditions hold, the two taxes also differ with respect to the wealth effects working through the impact on the owners of domestic and foreign assets. ${ }^{33}$ We return to this difference below.

\footnotetext{
32 See, for example, Lockwood (2001).

${ }^{33}$ See Auerbach (1997), Bond and Devereux (2002).
} 
A destination-based cash flow tax would thus have desirable properties: the scale and location of investment, and the use of different forms of finance, would all be unaffected by the tax. There would also be no incentive to shift profits to low tax-rate jurisdictions, an advantage which applies even if the above conditions for equivalence hold. Offsetting this is the underlying need for the source country to give relief for the cost of labour, even if the final good is exported and hence not taxed in that jurisdiction.

A characteristic of the destination-based corporate cash-flow tax is that it relinquishes the claim to domestic location-specific production rents. By imposing a tax based on destination, a country forgoes any attempt to tax rents that accrue to companies as a result of operating in its jurisdiction (source-based rents) as well as rents that might accrue as the result of residence. The corporate cash-flow tax, like a VAT, is a tax on domestic consumption. (Since labour income is not taxed, it differs from VAT in being a tax on domestic consumption from non-labour income.) It therefore imposes no burden on the consumption of those abroad who benefit from local rents. On the other hand, it does impose a tax on the location-specific rents at home and abroad that accrue to domestic consumers. Thus, a country with considerable location-specific rents might lose by adopting a destination-based tax, but even in this case the loss might be offset by the advantages already discussed.

Potential problems with implementing this proposal arise in transition. As noted above, the distinction between old and new investment is a general problem in moving towards a tax based on economic rent, whether a flow-of-funds tax or an ACE. A related concern arises with the destination-based tax. That is, the transition could generate important valuation effects. Compared to a source-based tax, a destination-based tax alleviates tax on exports and imposes a tax on imports. With flexible exchange rates, such border adjustments should lead to a revaluation of the domestic currency, thereby creating positive windfalls for foreign owners of domestic assets and negative windfalls for domestic owners of foreign assets. ${ }^{34}$ With fixed

\footnotetext{
${ }^{34}$ If the home country's international asset position is in balance, net windfalls will equal zero but the distributional effects will remain. These wealth effects are closely related to those already discussed that affect existing domestically-owned domestic assets. To see this, note that the international accounts identity implies that the capital and current accounts balance. Thus, a deduction for exports and a tax on imports is equivalent to a tax deduction for foreign investment and a tax on gross investment income earned abroad plus a tax on inbound investment and a tax deduction for gross domestic earnings repatriated by foreign owners. Hence, border adjustments amount to the imposition of a positive cash flow tax on outbound investment and a negative cash flow tax on inbound investment, leading to taxes on existing domestically-owned capital abroad and subsidies of existing foreign-owned domestic capital.
} 
exchange rates or within a common currency area, such revaluations would still occur in the presence of fully flexible prices, through an increase in the relative domestic price level. The situation would become more complicated with fixed exchange rates and sticky prices, with the destination-based tax potentially providing an output stimulus via a reduction in the real exchange rate.

A further question is whether a destination-based flow of funds tax would be creditable against any tax levied by a capital-exporting country. Since a destination-based tax appears less similar to a conventional corporate profits tax than a source-based flow of funds tax, then arguably it is even less likely to be creditable. Suppose the UK introduced a destination-based flow of funds tax, but no other countries followed suit. A foreign-owned company which operated in the UK but which exported all its output would have no positive UK taxable income (and indeed would probably have a UK taxable loss). The UK tax regime itself would be neutral with respect to the location decision of the multinational; while source-based taxes in other countries would generate an advantage to the UK. But a residence-based tax in the residence country of the multinational might outweigh this advantage. ${ }^{35}$

It is also worth commenting on the likely overall revenue implications of implementing this tax. We have discussed above the likely costs of introducing an R-base on a conventional source basis. Compared to this, a destination-based tax would give relief for exports, but would tax imports. Over the long run, we might expect the balance of trade to balance: in this case, the revenue implications would be the same as for the source-based tax. Clearly, though, in the shorter run, revenues would be higher or lower depending on whether the trade balance was in deficit or surplus.

\subsubsection{Taxing financial income}

Like Meade’s R-base flow-of-funds tax, a VAT-style destination-based flow-of-funds tax would not tax financial income. If only real flows were included in the tax base, then economic rent generated through an interest rate spread would be excluded.

\footnotetext{
${ }^{35}$ It is even possible that the "taxable loss" arising in the UK would become taxable in the residence country, further diminishing the benefit of the destination-based flow of funds tax.
} 
However, Meade's R+F base does tax the economic rent generated on the interest rate spread. ${ }^{36}$ As outlined in Section 2, the $\mathrm{R}+\mathrm{F}$ base includes flows of debt finance in the tax base. Specifically, inflows of debt and interest receipts are taxed, while debt repayments and interest payments receive tax relief. In effect, this is therefore a tax on the net present value of net lending by the corporate sector. As such, it should in principle be neutral with respect to real and financial decisions.

It would be possible to introduce the $\mathrm{R}+\mathrm{F}$ base on a destination-basis, in a similar way to introducing the R-base on a destination-basis. This would mean that only domestic transactions would be included in taxable income: border adjustments would apply to transactions with nonresidents. For example, borrowing from a foreign bank would not generate taxable income; neither would its repayment be relieved from tax. Conversely, lending to a foreign company would also not generate tax relief, and the return from such lending would not be taxable. This mirrors the exemption of exports in that sales of goods to non-residents would also not be taxed. However, tax would be levied on the economic rent generated by domestic borrowing and lending by banks.

Introducing such a destination-based $\mathrm{R}+\mathrm{F}$ tax raises three issues worth discussing.

First, there is again a similarity to VAT. In most countries, financial services are exempt VAT. Under the credit-invoice system, effectively a final tax is paid by banks on their inputs. No further charge is levied on transactions with the banks' customers. The resulting distortions have been the subject of a wide literature, including a literature on how VAT could be levied on financial services. ${ }^{37}$ The most well-known proposals for doing so are effectively a destinationbased $\mathrm{R}+\mathrm{F}$ base, as described here, applied to financial companies: the main difference from that proposed here is simply that for a VAT, labour costs would not be deductible. Variants on the pure $\mathrm{R}+\mathrm{F}$ base have been proposed which are very similar to the ACE: instead of an immediate tax on borrowing, the tax charge could be instead carried forward with an interest mark-up to offset against the eventual relief on the repayment with interest. ${ }^{38}$

\footnotetext{
${ }^{36}$ A "generalised" version of the R+F base, along the lines of the ACE system, is analysed by Bond and Devereux (2003).

${ }^{37}$ See, for example, Hoffman, Poddar and Whalley (1987), Merrill and Edwards (1996) and Poddar and English (1997). De la Feria (2007) provides a description of the current state of play in the EU.

${ }^{38}$ This is the "truncated cash-flow method with tax calculation account" of Poddar and English (1997).
} 
Second, the R+F base requires the tax system to make a distinction between debt and equity. (Of course, the R-base requires a distinction between real and financial flows). The distinction is much less important than under conventional corporation taxes, though, because only the economic rent arising from debt transactions would be taxed. However, as already discussed, there would be an incentive for a company to issue equity and debt to related parties and to make deductible payments to debt rather than non-deductible payments to equity. Care would also be required to impose appropriate tax treatment for hybrid instruments, such as equity which could be converted into debt. Issuing equity would not yield a tax charge (unlike issuing debt), but repaying the investment as debt, with interest, would receive tax relief. In this instance, the appropriate treatment of such a hybrid instrument would be that the act of conversion from equity to debt would be taxable.

The third issue concerns the UK in particular: currently the UK generates considerable revenue from corporation tax levied on the profits of resident financial companies. Part of this stems from the international activities of financial companies resident in the UK. A destination-based R+F base would raise revenue only on economic rent generated on lending within the UK. Introducing such a tax may therefore have a negative impact on UK taxable income.

\subsubsection{Destination-based income taxation}

Given the advantages of a destination-based corporate tax over a source-based tax, it is worth considering whether a similar approach might be taken in the context of an income-based tax, rather than a flow-of-funds tax. To rely on the previous analysis as much as possible, consider the conversion of a destination-based flow-of-funds tax into a destination-based income tax, accomplished by providing only a fractional deduction for the purchase of investment goods. ${ }^{39}$ The company's tax base would be higher than under a pure flow-of-funds tax, as expected, but it would now also have an incentive to understate the prices of investment goods produced by a subsidiary, foreign or domestic, since it would get to deduct only part of the cost of the investment. It is unclear how big a problem this is. To the extent that most capital expenditures are at arm's length, then a destination-based approach to income taxation might be feasible, but, feasibility aside, it is not clear under what circumstances it would be desirable to impose an

\footnotetext{
${ }^{39}$ This is the approach suggested in the domestic context by Auerbach and Jorgenson (1980).
} 
income tax on a destination basis. That is, one would need to consider why a country might wish to tax on a destination basis the capital income (as opposed simply to economic rent) associated with its domestic activities.

\section{Conclusions}

This paper has considered the design of taxes on corporate income. We began with the proposals of the Meade Committee (1978) for a flow-of-funds tax, and analysed how these proposals fare thirty years later, in the light of important developments in economies and economic thought.

We considered two principal dimensions in the choice of a tax on corporate income. The first dimension is the base of the tax. Here we compared a standard corporation tax, levied on the return to shareholders with two alternatives: a tax on economic rent, as proposed by the Meade Committee, and a tax on the return to all capital, such as under the Comprehensive Business Income Tax and the dual income tax. The second dimension is geographic: where should the income be taxed? Here we contrasted the typical approach of source-based taxation to the alternatives of residence and destination bases.

The "optimal" tax system depends partly on why the tax is levied. If it is intended to be a substitute for taxing the capital income of domestic residents, then its form could be very different from the case in which it is intended to capture the location-specific rent earned by nonresidents. Given the increasing cross-ownership of shareholdings across countries, using a source-based tax on corporate income as a substitute for a residence-based tax on shareholders seems increasingly problematic. In open economies, much domestic economic activity is owned and controlled by non-residents; conversely, much of the accretion to wealth of residents takes place abroad. The argument for taxing source-based economic rent depends on the extent to which that rent is location-specific. At one extreme case (equivalent to a closed economy) all rent is location-specific and can therefore be captured in tax without distorting investment. But at the other extreme, it is possible that little or no rent is location-specific: companies could earn equivalent profit by locating their activities elsewhere. In the latter case, a source-based tax on rent (such as proposed by the Meade Committee) could divert economic activity abroad, where it could face a lower tax rate. 
One important aspect of the Meade proposals was to avoid a distinction in the tax system between debt and equity. Meade considered two proposals, each of which effectively eliminated the distinction. Avoiding this distinction has become an even more important issue since, as the boundaries between the two forms of financial instrument have become increasingly blurred. That consideration points to a tax which falls either on the whole return to investment, or only on economic rent. However, this is not straightforward either, since in either case the tax base still requires that distinctions be made either between real and financial income flows or between debt and equity. There is no obvious way to simultaneously avoid distinctions. Differentiating between real and financial flows also creates additional problems in taxing the income of financial companies.

Moving from predominantly source-based corporate taxation to residence-based taxation is not an attractive option. Taxing corporate income in the hands of the parent company is in any case more like source-based taxation, since the location of the parent is not fixed. So true residencebased taxation would have to be at the level of the individual investor; but in a globalised world, this is scarcely feasible.

An alternative which we have put forward for serious consideration is a destination-based tax, levied where a sale to a final consumer is made. In fact, we formulate a simple - though farreaching - extension of the flow-of-funds taxes of Meade. Specifically, we suggest that one might improve on Meade’s proposed taxes by adding border adjustments: imports would be taxed, but tax on exports would be refunded. The result is a destination-based cash-flow tax, essentially a destination-based VAT, but with labour costs deductible. We believe that there is a good case for implementing such a tax on an $\mathrm{R}+\mathrm{F}$ basis, rather than on an R-basis, on the grounds that this would also tax the economic rents generated by banks on lending to domestic borrowers. $^{40}$

Such a tax would leave discrete location choices unaffected by the tax, and would also considerably lower the opportunity for companies to shift profits between countries. One implication of such a tax is that a country introducing it would need to give relief for labour costs

\footnotetext{
${ }^{40}$ Whether the $\mathrm{R}+\mathrm{F}$ base would apply only within the financial sector, as others have proposed in the context of existing VATs, or to all businesses is an issue that requires further consideration.
} 
borne in the production of untaxed exports. The neutrality advantages of such a tax to a system are somewhat less clear if the normal return to domestic capital is to be taxed. 


\section{References}

Altshuler, R. and Auerbach, A.J. (1990), “The significance of tax law asymmetries: an empirical investigation”, Quarterly Journal of Economics, 105(1), 61-86.

Altshuler, R. and Goodspeed, T. (2002), "Follow the leader? Evidence on European and US tax competition”, Departmental working papers, 200226, Rutgers University, Department of Economics.

Auerbach, A. (1979), “Wealth maximization and the cost of capital”, Quarterly Journal of Economics, 93(3), 433-46.

Auerbach, A. (1983), “Corporate taxation in the United States”, Brookings Papers on Economic Activity, vol. 1983(2), 451-505.

Auerbach, A. (1997), “The future of fundamental tax reform” American Economic Review, 87(2), 143-146.

Auerbach, A. (2002), “Taxation and corporate financial policy”, in Auerbach, A. and Feldstein, M. eds., Handbook of Public Economics, vol. 3, 1251-92.

Auerbach, A. (2006), “The future of capital income taxation”, Fiscal Studies, 27(4), 399-420.

Auerbach, A. and Hassett, K. (2007), “The 2003 dividend tax cuts and the value of the firm: an event study”, in Auerbach, A., J. Hines, and J. Slemrod, eds., Taxing Corporate Income in the 21st Century, 93-126.

Auerbach, A. and Jorgenson, D. (1980), “Inflation-proof depreciation of assets” Harvard Business Review, September/October, 113-118.

Auerbach, A. and King, M. (1983), “Taxation, portfolio choice and debt-equity ratios: a general equilibrium model”, Quarterly Journal of Economics, 98(4), 588-609.

Auerbach, A. and Slemrod, J. (1997), “The economic effects of the Tax Reform Act of 1986” Journal of Economic Literature, 35(2), 589-632.

Bradford, D. (1981), “The incidence and allocation effects of a tax on corporate distributions”, Journal of Public Economics, 15(1), 1-22 
Berle, A. and Means, G. (1932), The modern corporation and private property, Macmillan: New York.

Black, F. and Scholes, M. (1973), “The pricing of options and corporate liabilities” Journal of Political Economy, 81(3), 637-654.

Boadway, R. and Bruce, N. (1984) “A general proposition on the design of a neutral business tax” Journal of Public Economics, 24(2), 231-239.

Bond, S. (2000), "Levelling up or levelling down? Some reflections on the ACE and CBIT proposals and the future of the corporate tax base”, in Cnossen, S. ed. Taxing capital income in the European Union: issues and options for reform, Oxford: OUP

Bond, S. and Devereux, M.P. (1995), “On the design of a neutral business tax under uncertainty”, Journal of Public Economics, 58(1), 57-71.

Bond, S. and Devereux, M.P. (2002) “Cash flow taxes in an open economy”, CEPR Discussion Paper 3401.

Bond, S. and Devereux M.P. (2003), “Generalised R-based and S-based taxes under uncertainty”, Journal of Public Economics, 87(5-6), 1291-1311.

Chamley, C. (1986), “Optimal taxation of capital income in general equilibrium with infinite lives”, Econometrica, 54(3), 607-622.

Crawford, C. and Freedman, J. "Small business taxation”, this volume.

Cummins, J., Hassett, K. and Oliner, S. (2006) "Investment behaviour, observable expectations and internal funds”, American Economic Review, 96(3), 796-810.

De la Feria, R. (2007) “The EU VAT treatment of insurance and financial services (again) under review”, EU Tax Review 2007.2, 74-89.

Desai, M.A. and J. Hines Jr. "Expectations and Expatriations: Tracing the Causes and Consequences of Corporate Inversions " National Tax Journal 55.3, 409-440.

Devereux, M.P. and Griffith, R. (1998), “Taxes and the location of production: evidence from a panel of US multinationals”, Journal of Public Economics, 68(3), 335-367. 
Devereux, M.P., Griffith, R. and Klemm, A. (2002), “Corporate income tax reforms and international tax competition”, Economic Policy, vol. 17, issue 35, 451-495.

Devereux, M.P., Griffith, R. and Klemm, A. (2004), "Why has the UK corporation tax raised so much revenue?” Fiscal Studies, vol. 17, issue 35, 451-495, 25(4), 367-388.

Devereux, M.P., Lockwood, B. and Redoano, M. (2006), “Do countries compete over corporate tax rates?”, Oxford University Centre for Business Taxation working paper.

Devereux, M. P. and Sørensen, P.B. (2005), “The corporate income tax: international trends and options for fundamental reform”, EPRU-Analysis No.24. http://www.econ.ku.dk/epru

Diamond, P. and Mirrlees J, (1971), “Optimal taxation and public production I-II”, American Economic Review, 61, 8-27 and 261-278.

Fazzari, S., Hubbard, R. G., and Petersen B. (1988), "Financing constraints and corporate investment” Brookings Papers on Economic Activity, vol. 1988(1), 141-195.

Feldstein, M. and Horioka, C. (1980), “Domestic saving and international capital flows” Economic Journal, vol. 90, no.358, 314-329.

Graham, J.R. (1996), “Debt and the marginal tax rate”, Journal of Financial Economics, 41, 4173.

Griffith, R., Hines, J. and Sørensen, P.B. “International taxation”, this volume.

Goolsbee, A. (1988), “Taxes, organizational form and the deadweight loss of the corporate income tax”, Journal of Public Economics, 69(1), 143-152.

Gordon, R., Kalambokidis, L. and Slemrod, J. (2004), “Do we now collect any revenue from taxing capital income?”, Journal of Public Economics 88, 981-1009.

Gordon, R. and Mackie-Mason, J. (1997), “How much do taxes discourage incorporation?”, Journal of Finance, 52(2), 477-505.

Gordon, R. and Slemrod, J. (1988), “Do we collect any revenue from taxing capital income?”, Tax Policy and the Economy 2, 89-130.

Gordon, R. and Wilson, R. (1986), “An examination of multijurisdictional corporate income taxation under formula apportionment,” Econometrica, 54(6), 1357-1373. 
Grubert, H. and T. S. Newlon (1995) "the International Implications of consumption tax proposals”, National Tax Journal, 48.4, 619-47.

Grubert, H. and T. S. Newlon (1997) “Taxing Consumption in a Global Economy”, Washington D.C.: American Enterprise Institute.

Harberger, A. (1962), “The incidence of the corporation income tax”, Journal of Political Economy, 70(3), 215-240.

Haufler, A. and Schjelderup, G. (2000), “Corporate tax systems and cross country profit shifting”, Oxford Economic Papers, 52(2), 306-325.

Hoffman, L.A., S.N. Poddar and J. Whalley (1987) “Taxation of banking services under a consumption type, destination-based VAT”, National Tax Journal 40, 547-554.

Horstman, I. and Markusen, J. (1992), “Endogenous market structures in international trade” Journal of International Economics, 32, 109-129.

IFS (1991), Equity for companies: a corporation tax for the 1990s, IFS Commentary C026. London: Institute for Fiscal Studies.

Jensen, M. (1986), “Agency costs of free cash flow, corporate finance, and takeovers” American Economic Review, 76(2), 323-329.

Judd, K. (1985) “Redistributive taxation in a simple perfect foresight model”, Journal of Public Economics, 28(1), 59-83.

Keen, M. and Piekkola, H. (1997), "Simple rules for the optimal taxation of international capital income”, Scandinavian Journal of Economics, 99(3), 447-461.

King, M. (1974), “Taxation and the cost of capital” Review of Economic Studies, 41(1), 21-35.

King, M. and Fullerton, D. (1984), The taxation of income from capital: a comparative study of the U.S.,U.K., Sweden and West Germany, Chicago: University of Chicago press.

Kleinbard, E. (2007), “Designing an income tax on capital”, in Taxing Capital Income, Steurele, C.E. , Burman, L.E. and Aaron, H.J. eds, Washington, DC: Urban Institute Press.

Lockwood, B. (2001), “Tax competition and tax co-ordination under destination and origin principles: a synthesis”, Journal of Public Economics, 81(2), 279-319. 
Markusen, J. (2002), Multinational firms and the theory of international trade, Cambridge: MIT Press.

McLure, C. (1980), “The state corporate income tax: lambs in wolves’ clothing” in The economics of taxation, Aaron, H. and Boskin, M. eds. Washington, D.C: Brookings Institution

Meade Committee (1978), The structure and reform of direct taxation, London: Allen and Unwin.

Merrill, P.R. and C.R. Edwards (1996) “Cash-flow taxation of financial services” National Tax Journal 49, 487-500.

Miller, M. (1977), “Debt and taxes” Journal of Finance, 32(2), 261-275.

Nielsen, S.B. and Sørensen, P.B. (1997) "On the optimality of the Nordic system of dual income taxation” Journal of Public Economics, 63(3), 311-329.

Poddar, S.N. and M. English (1997) “Taxation of financial services under a Value-Added Tax: applying the cash flow approach”, National Tax Journal 50, 89-111.

Sinn, H-W. (1991), “The vanishing Harberger triangle”, Journal of Public Economics, 45(3), 271-300.

Sørensen, P.B. (1994) "From the global income tax to the dual income tax - recent tax reforms in the Nordic countries” International Tax and Public Finance, 1(1), 57-79.

Sørensen, P.B. (2005a) “Dual income taxation - why and how?” FinanzArchiv, 61(4), 559-586.

Sørensen, P.B. (2005b). "Neutral taxation of shareholder income” International Tax and Public Finance 12, 777-801.

U.S. Department of the Treasury (1992) Integration of the individual and corporate tax systems: taxing business income once, Washington D.C.: U.S. G.P.O.

Warren, A. C. (2004) “U.S. Income Taxation of New Financial Products,” Journal of Public Economics, 88(5), 889-923. 